CuPAUAM. 18-1991, 55-112

\title{
ENTERRAMIENTOS DEL HORIZONTE PROTOCOGOTAS EN EL VALLE DEL MANZANARES ${ }^{\text {(1) }}$
}

\author{
$M^{a}$ CONCEPCION BLASCO; $M^{a}$ LUZ \\ Sanchez Capilla; Juana Calle; \\ FRANCISCO J. ROBLES; V. M. \\ GONZALEZ Y A. GONZALEZ. \\ UNIVERSIDAD AUTONOMA DE MADRID
}

\section{1.- ESTUDIO ARQUEOLOGICO \\ $M^{a}$ Concepción Blasco: \\ $M^{a}$ Luz Sanchez Capilla; Juana Calle. \\ Departamento de Prehistoria y Arqueologia}

\section{Resumen}

El trabajo da a conocer la presencia de cinco enterramientas de inhumación (cuarro individuales y uno doble) dentro del ámbito de un poblado de la Edad del Bronce perteneciente al Horizonte Protocogotas. La escasez de este tipo de hallazgos y la variedad ritual que presentan confieren a estas manifestaciones un especial interés.

\section{Summary}

This work studies five inhumation's burials (four individual and one double) into a settlement of the Bronze Age of Protocogotas Horizon. The scarcity of this kind of finds makes more interesting this work.

Hasta hace poco tiempo el conocimiento que tenfamos del mundo funerario de la Edad del Bronce medio peninsular se reducla casi exclusivamente a los datos propocionados por la Cultura argárica que ha facilitado abundantes y expresivas manifestaciones a través de las cuales se han podido extraer interesantes datos de la más variada índole debido a la riqueza y variedad de sus aịuares y a la buena conservación de los restos antropológicos, aunque este último aspecto no había gozado de un estudio global hasta fechas recientes. Por el contrario los daros relativos a enterramientos

(1) Este trabajo ha sido subvencionado con el Proyecto del Plan General de ayuda a la Investigación de la Comunidad Autónona de Maćrid: "Patrimonio Arqueológico de las Cuencas bajas del Jarama y Marzanares" 
Bronce peninsular eran, y siguen siendo, muy parcos especialmente los procedentes de ambas mesetas.

En efecto, hasta el momento, sólo contamos con algunos enterramientos del Bronce meseteño procedentes de hallazgos fortuitos, generalmente descontextualizados, o de excavaciones muy limitadas y/o antiguas, con adscripciones culturales y cronológicas dudosa que no permiten extraer datos demasiado precisos. En su mayoría son enterramientos en fosa o cuevas cuya pertenencia a la Edad del Bronce y, más concretamente, a un determinado horizonte, no siempre resulta clara. La única excepción la constituyen los datos procedentes de hallazgos practicados en las Motillas manchegas (Najera y otros 1979) o en poblados de altura de Ciudad Real (Nieto G. y Sanchez Meseguer, J., 1980), aunque carecemos de memorias de excavaciones suficientemente decalladas en las que se haga un estudio minucioso sobre este aspecto. Sólo desde hace algunos años comenzamos a disponer de datos más concluyentes, siendo destacables los que nos ha brindado el yacimiento de La Loma del Lomo (Cogolludo, Guadalajara), (Valiente, Malla J., 1987a y b), tanto por el número de inhumaciones exhumadas como por su clara relación con un conjunto habitacional.

Dentro de esta ausencia tan generalizada de datos, son los Horizontes Protocogotas y Cogotas I, los que mayor número de datos han proporcionado, bien a través de hallazgos aíslados, bien por medio de excavaciones sistemáticas entre las que destacan, por el volumen de información, Los Tolmos de Caracena en Soria (Jimeno, 1984 y Jimeno, A. y Fernández Moreno, J. J., 1991, p.104) debido a la extensión de la superficie excavada y la fosa de inhumación triple de San Román de la Hornija por su detallado estudio (Delibes, G., 1978). Por otra parte con la información procedente de yacimientos que se inscriben en este marco o en ámbitos culturales más o menos sincrónicos, recientemente ha sido posible ofrecer una primera aproximación al problema del mundo funerario de la Meseta durante la Edad de Bronce (Esparza, A., 1990) y extraer unas primeras conclusiones.

Sin embargo, los enterramientos exhumados en el yacimiento del Caserío de Perales del Río (Getafe, Madrid) (Figura 1 y Lámina I, a) con diversos asentamientos de la Edad del Bronce inscritos en los horizontes Protocogotas y Cogotas I ofrecen, ellos solos, una información más completa que la procedente del resto de los datos que hasza ahora teníamos para esos círculos culturales. En primer lugar, por su encuadre dentro de un yacimiento del que se han excavado alrededor de 5 hectáreas, en segundo término, por la variedad ritual que presentan las inhumaciones descubiertas y por último, por su clara adscripción a una facies cultural concreta: El horizonte Protocogotas I, por ello nos parece interesante ofrecer la primicia de estos hallazgos dentro del marco en que se localizaron.

\section{LAS FOSAS DE ENTERRAMIENTO}

Fondo 30. Cuadricula 18: (PR-01 del Estudio antropológico)

(Figura 2 y Lámina I, b)

\section{La subestructura}

La deposición de la inhumación se practicó en una fosa de planta circular y sección en forma de saco, con un cuello que diferencia la boca del resto del fondo. Medía 130 por 128 centímetros de diámetros de boca y 136 por 125 centímetros de diámetro de base. La altura total conservada era de 108 centímetros. En la pared, junto a la base de la fosa y en su zona oeste se había abierto un covacho de unos 60 centímetros de altura pot 50 centímetros de fondo que sirvió para alojar la inhumación. 


\section{El enterramiento}

El cadáver se colocó en posición flexionada siguiendo un eje norte-sur, con la cabeza en el lado sur y mirando hacia el este. Se apoyaba sobre el lado derecho y presentaba la mano derecha apoyada en el mentón, mientras que la mano izquierda estaba colocada a la altura de tibia y peroné. Se trata de un varón joven, de entre 20 y 25 años de edad con una estatura de alrededor de 1'57 metros.

\section{El contenido de la fosa}

El covacho donde se alojaba el difunto no presentaba piedras de cietre apareciendo colmatado exclusivamente con un sedimento geológico muy apelmazado similar al que rellenaba el resto de la fosa. Dichas tierras eran muy compactas, y de color marronáceo, salvo las que estaban más próximas a la inhumación que eran de tonalidad más grisácea. Entre todas estas tierras se recogieron restos de huesos animales de pequeño tamaño así como 163 fragmentos de cerámica, también de escasas dimensiones lo que no favorece la reconstrucción de tamaños y formas de los recipientes a los que pertenecieron. Los únicos datos de interés eran la existencia de algunas carenas marcadas y la presencia de un pequeño fragmento decorado con incisiones en forma de espiga y otro con zig-zags también incisos. Tanto las carenas marcadas como los pocos datos ornamentales nos invitan a suponer que se trata de un enterramiento de la fase protocogotas, hipótesis que se ve reforzada por los materiales exhumados en los hoyos próximos.

Todo el material mueble recuperado en la fosa se encontraba disperso y a diferentes profundidades, observándose una mayor concentración en la parte superior ya que en los 20 centímetros que cerraban el conjunto se recogí algo más del $50 \%$ de la cerámica recuperada, concretamente 88 de los 163 fragmentos localizados. Por otra parte, nos se encontró ningún elemento mueble en relación directa con la inhumación lo que nos permite pensar que los escasos restos localizados proceden de los restos de desechos existentes en el suelo de ocupación que cayeron en la fosa en el momento en que se selló con tierras procedentes de la superficie.

En el momento de la excavación no se indentificó ningún tipo de piedra u otro tipo de indicador que pudiera haber señalizado el enterramienro, no obstante el artasamiento del suelo de ocupación antes de que se produjera nuestra actuación pudo haber sido la causa de la desaparición de posibles indicadores si es que éstos existieron, cosa que parece posible si tenemos en cuenta su situación dentro de los límites de la ocupación habitacional y la similitud de la fosa de inhumación con el resto de las subestructuras localizadas.

\section{Fondo 21. Cuadrícula 43: (PR-04 del estudio antropológico).}

$$
\text { (Figura } 3 \text { y Lámina II, a) }
$$

\section{La subestructura}

La inhumación se practicó en una fosa de planta circular y sección de tendencia cilíndrica con los lados ligeramente convergentes hacia la boca. El diámetro superior era de 1,28 y el de base de 1,10, mientras que la altura conservada totalizaba 1,16 metros. En la zona noreste de las paredes se abrió un covacho de sección cónica cuya base tenía un tadio de 0,60 metros el cual se utilizó para alojar el cadáver. La concentración de piedras de tamaño relativamente grande (en torno a los 
30 centímetros de nódulo), localizada en el interior de la fosa, nos permite suponer que, aunque algunas de ellas estaban claramente sellando el covacho donde se depositó la inhumación, otras pudieron formar parte de una acumulación intencionada que pudo incluso coronar la cota de tiera de la fosa sirviendo así de indicador aunque en el momento de la excavación no se pudo constatar este extremo.

\section{El enterramiento y su ajuar}

Como en el caso anterior, la inhumación se depositó en el covacho abierto para tal fin en la parte baja de las paredes de la fosa. Estaba en posicion fuertemente contraída, y siguiendo un eje aproximado Este-Oeste; la cabeza se encontraba en el lado oeste y mirando hacia el sur; se apoyaba sobre el lado izquierdo, tenía la mano derecha sobre la izquierda y ambas a la altura del mentón izquierdo. Se trata de una mujer adulta, de entre 30 y 35 años. La altura estimada oscila entre 1,52 y 1,58 .

Presentaba un único elemento claro de ofrenda: una cazuela con carena media bastante acusada que tiene 11,4́ centímetros de diámetro y 5,6 centímetros de altura (Fig. 4, 3). El recipiente se halló colocado junto a la cabeza, concretamente, a la altura del parietal izquierdo. Además, no se puede descartar la posible relación de esta inhumación con los abundantes restos óseos animales depositados en una fosa-chimenea estrecha y profunda situada a escasos centímetros de la del enterramiento. De ser así, es posible que nos encontremos ante los restos de un posible banquete ritual $o$, simplemente, ante el acopio de comida para el sustento del difunto.

\section{El contenido de la fosa}

La fosa utilizada para la inhumación se encontró colmata por un relleno geológico más fino y compacto en las cotas superiores (hasta -20 centimetros) que en el resto donde presentaba una textura de grano medio o grueso; tenía un tono oscuro de color marronáceo que se convertía en grisáceo en la zona más próxima al enterramiento. En la parte inferior de las paredes del fondo de la zona noreste se acumulaban varios bloques de sílex cuarcitas y yesos, procedentes de la zona, con un módulo en torno a los 30 centímetros. Aunque algunos de ellos se encontraban algo desplazados, su disposición hacía pensar que su función era la de sellar el covacho destinado a alojar la inhumación.

Entre estas piedras sólo una era de procedencia foránea, se trata de un granito, que había sido utilizado como molino y que se encontraba situado, en el centro de la parte inferior de la fosa por lo que, aunque no se puede descartar que formara parte del sellado del covacho, muy desplazado de su posición originaria, tampoco es improbable que estemos ante un elemento de ajuar.

Entre el relleno geológico se recogieron también abundantes restos óseos de fauna, un total de 201 fragmentos cerámicos de diversos tamaños y un elemento de hoz realizado en sílex (Figura 4). La fauna se encontraba especialmente concentrada en el nivel de cierre de la boca de la fosa, decreciendo paulatinamente en los niveles inferiores para desaparecer, al igual que la cerámica, a partir de la cota de -100 , ya que los 20 centímetros inferiores resultaron totalmente estériles. Los 201 fragmentos cerámicos aparecieron dispersos en los diferentes estratos, sin que se observara una concentración especial en ninguno de ellos, salvo en el nivel de cierre de la fosa $(0$ a 10 centímetros). Esta dispersión de hallazgos y la importante fragmentación nos permite suponer que, tanto huesos como cerámicas, fueron introducidos de manera accidental al echar las tierras con las que se selló la fosa. 
La característica formal más significativa de los fragmentos recogidos en esta fosa (Fig. 4), así como la del cuenco colocado sobre la cabeza del difunto, es la presencia, relativamente abundante, de carenas medias o bajas, un dato que nos permite pensar que estamos ante un horizonte Protocogotas o un Bronce Pleno ligeramente anterior. En todo caso están ausente las características ornamentaciones incisas o impresas desarrollando espiguillas y zig-zags y las únicas decoraciones presentes en este conjunto son las impresiones e incisiones en algunos labios y escasos mamelones plásticos cuya cronología y adscripción cultural no es significativa. A pesar de ello estimamos que este enterramiento, dadas sus características, similares al anteriormente descrito y las propias formas cerámicas podría enmarcarse dentro de la facies Protocogoras documentada en el yacimiento.

\section{Fondo 23. Cuadricula 31: (Pr-05 y PR-06 del estudio antropológico).}

$$
\text { (Figuras 5, } 6 \text { y } 7 \text { y Lámina } 1, c y d \text { ). }
$$

\section{La subestructura}

Se trataba de una fosa con planta oblonga en la boca y casi circular en la base, tenía sección irregular, con las paredes convergentes hacia la boca en unas zonas y divergentes en otras. Los diámetros de boca eran 1,28 por 1,68 merros y los de base 1,50 por 1,56. La altura conservada en el momento de la excavación era de 0,50 metros. Aunque no se apreció ningún resto de manteado "in situ", forrando paredes o suelos, sí se recogieron en el interior de la cubeta algunos fragmentos que podían proceder de un posible acondicionamiento de la subestructura cuya escasa profundidad y relativa anchura de diámetro de boca la hace notablemente distinta a las dos anteriormente comentadas.

\section{El enterramiento y su ajuar}

La subestructura que nos ocupa fue preparada pata recibir una doble inhumación correspondiente a dos individuos infantiles. Los cuerpos se colocaron en la parte central de la cubeta, a tan sólo 6 centímetros de la superficie existente en el momento de la excavación. La escasa potencia de tierra que sepataba los cuerpos del suelo actual y la escasa consistencia de los huesos infantiles favoreció el mal estado de la conservación en que se encontraban. Los cadáveres se depositaron entrelazados, en posición flexionada y siguiendo un eje norte-sur, con las cabezas hacia el norte. Estaban afrontados de manera que uno de ellos se apoyaba sobre el lado izquierdo, mirando hacia el Este y el otro sobre el lado derecho mirando hacia el oeste (Figura 5).

Bajo los cuerpos se preparó un lecho de gruesos fragmentos cerámicos, pertenecientes a varios recipientes los cuales proporcionaban un aislamiento. Además el perimetro de la fosa se indicó mediante un alineamiento de cantos rodados interrumpido en algunos tramos, dicho alineamiento se encontraba en la base de la fosa, es decir, muy por debajo de las inhumaciones.

El único elemento de ofrenda claro era un cánido colocado a los pies de los inhumados del que sólo se conservaba la mitad delantera. Estaba colocado, como los restos humanos, en un eje nortesur, aunque con la cabeza hacia el sur y mirando hacia el oeste. También existía una pequeña acumulación de fragmentos cerámicos colocada a la altura de las inhumaciones pero desplazada junto a la pared noreste de la fosa, no obstante su función no resulta del todo clara ya que no había piezas compleras y los fragmentos pertenecían a recipientes de desigual calidad. Entre las tierras que colmataban la fosa se obtuvo también una pesa de telar discoidal con orificio central (Figura 5, 2) 
y un fragmento de molino que, al no estar en relación directa con las inhumaciones, resulta dificil interpretar como elementos de ajuar.

Los restos corresponden a sendos infantes de 9 y 5 años, el mayor de los cuales presentaba evidencias de anemia o manutrición, la posición entrelazada certifica que la deposición de ambos cuerpos fue simultánea. El mal estado de conservación de los huesos debido a la fragilidad de los mismos y a su localización a muy pocos centímetros de la superficie, no ha facilitado obtener una buena información sobre talla y patologias.

\section{El contenido de la fosa}

La subestructura se encontraba colmatada por tierras de color amarillento, a excepción de las que rodeaban a los restos humanos que eran marrones o grisáceas de tono oscuro, fruto de la descomposición de la materia orgánica. Estaban escasamente compactadas y eran de grano medio o fino. Como ya se ha apuntado, había también fragmentos de manteado y abundantes piedras, especialmente cantos rodados, además de algunos silex y un granito perteneciente a un molino amortizado. Los fragmentos cerámicos recuperados en esta fosa ascendían a 228 los cuales aparecieron concentrados bajo las inhumaciones, formando un lecho, y agrupados, a escasa profundidad de la superficie, junto a la pared noreste de la subestructura.

A diferencia de los enterramientos antes comentados, la disposición de la cerámica en esta fosa hace pensar que su intrusión no fue casual sino intencionada, ello explicaría también su mayor tamaño. Estos fragmentos pertenecen a dos tipos de recipientes: cuidados y comunes (Figs. 5, 6 y 7). Los primeros presentan superficies pulidas, incluso bruñidas, y con frecuencia tienen decoración de incisiones o impresiones creando zig-zags o espiguillas y en una ocasión, triángulos rellenos de puntillado (Lámina IV, d, e y f́). Algunos ejemplares más toscos combinan las incisiones en zig-zag con mamelones plásticos (Lámina $\Gamma \mathrm{V}, \mathrm{g}$ y h) los cuales aparecen en ocasiones como único elemento ornamental. Entre los perfiles destacan, por su significado, las carenas medias bastante acusadas, aunque no faltan tampoco las tipologias más sencillas de cuencos hemisféricos y ollas ovoides. Además de los recipientes, hay que mencionar la presencia de una pesa de telar discoidal con otificio central (Fig. 5, 2).

Las características de este material cerámico nos permire adscribir estas inhumaciones a una facies Protocogotas muy clara y, por ranto, corresponderian a un hotizonte similar a los enterramientos antes descritos, sin que sea posible precisar si pertenecen a la misma ocupación.

Fondo 11. Cuadrícula 43: (PR-07 del estudio antropológico).

(Fig. 8 y Lámina II, b, c y d).

\section{La subestructura}

Se trataba de una fosa de planta oval y sección casi cilíndrica. Medía 2 por 1,20 metros de diámetro de boca y 1,30 metros de altura conservada. Tenia, por tanto, un volumen superior al de las otras fosas. No presentaba ningún tipo de acondicionamiento de paredes y suelo y tampoco nichos u hornacinas; la única circunstancia digna de mención era la gran acumulación de piedras colocada sobre un nivel de tierra verdosa de entre 10 y 15 centímetros de potencia que cubría totalmente la inhumación junto con dos bloques de yeso colocados uno a la altura de las caderas y otro 
a la altura de la cara que estaban prácticamente en contacto con los huesos humanos. El resto de la fosa, hasta el nivel de superficie se rellenó con tierra procedente del entorno que contenía algún resto cerámico. Sobre la superficie se conservaba otra acumulación de piedras que sellaba el fondo y facilitaba su localización.

\section{El enterramiento}

La inhumación se depositó en el fondo de la fosa, a poco más de un metro de profundidad, ligeramente desplazada hacia el noroeste, junto a ella no se recogió ningún material que pudiera haber pertenecido a un posible ajuar. El cadáver se colocó de forma transversal al eje mayor de la fosa, en posición flexionada, apoyado sobre el lado izquierdo, con la cabeza al Oeste y los pies hacia el Este. Tenía la cara vuelta mirando hacia arriba y la mano derecha apoyada en el mentón, mientras que la izquierda estaba colocada sobre la muneca izquierda.

El individuo enterrado era una mujer adulta, de entre 30 y 42 años, cuya estatura pudo oscilar entre 1,65 y 1,62. Su buena conservación ha permitido saber que se trababa de una mujer fértil con deformaciones en la escápula posiblemente producidas por reiterada carga.

\section{El contenido de la fosa}

El relleno de la fosa estaba constituido por un nivel inferior consistente de tierras verdosas, echadas sobre la inhumación que únicamente tenía en contacto con la cabeza y la cadera respectivamente dos grandes piedras. Sobre este nivel, carente de material arqueológico, se colocó un amontonamiento de 77 piedras procedentes de la propia terraza fluvial en la que se encuentra el yacimiento a excepción de dos fragmentos de granito, uno de ellos correspondiente a un molino amortizado. Esta acumulación se colocó prácticamente en el centro de al fosa y, por tanto, ligeramente desplazada de los restos humanos, un detalle que se entiende si se tiene en cuenta que se encontraban ya totalmente cubiertos por la primera capa de tierra.

Por encima de estas piedras, los 60 centímetros superiores de la fosa fueron rellenos con tierra procedente del entorno y entre ella se mezclaron fragmentos de cerámica, 47 en total, y 19 restos óseos animales. Sobre la boca de la fosa, posiblemente como elemento indicador del enterramiento, se colocó un segundo enlosado que se conservaba perfectamente visible en el momento de la excavacion.

El escaso tamaño de los fragmentos cerámicos y la falta de ornamentación impiden su adscripción cultural ya que sólo un fragmento (Fig. 8,2 ) presenta una serie de impresiones paralelas en el labio y un mamelón en el cuello, desgraciadamente se trata de una decoración de escasa precisión cronológica y cultural. Por otra parte las diferencias existentes entre ésta y las otras inhumaciones exhumadas favorecen muy poco el establecimiento de paralelos. No obstante el contenido de los fondos próximos al enterramiento permite suponer que podemos estar también ante una inhumación del horizonte Protocogotas.

El aspecto más peculiar de este enterramiento lo constinzye la gran acumulación de piedras, tanto del interior de la fosa como en su coronamiento, no obstante se trata de un elemento que tiene sus paralelos en las piedras que sellan el covacho de la segunda de las inhumaciones comentadas y, sobre todo, en el enlosado identificado en San Román de la Hornija, donde también se coloc6, sobre una primera capa de tierra que cubría los cadáveres (Delibes, 1978, p. 238, fig 2). Si bien lo más interesante es el enlosado de coronamiento el cual puede ser indicio de que la coloca- 
ción de indicadores de piedra e, incluso de sellados a base de bloque líticos que permitian conocer el punto exacto de los enterramientos.

Fondo 20. Cuadricula 34/35: (PR-03 del estudio antropológico).

(Figs. 9 y 10 y Lámina III, a, b y c).

\section{La subestructura}

La deposición de los restos humanos se practicó en una fosa de planta circular y sección acampanada con la zona más abierta hacia arriba. Medía 1,27 metros de diámetro de boca y 1,07 de diámetro de base. La altura conservada en el momento de la excavación era de 50 centímetros. No encontramos ningún tipo de hornacina ni repisa y tampoco se documentaron restos de manteados o revoco de las paredes. La única preparación constatada era un lecho o cama realizado con fragmentos de cerámica pertenecientes a recipientes comunes de gran tamaf́o, varios de ellos de forma muy similar y cuyo diámetro alcanzaban en torno a los 0,50 metros. Sin embargo el hecho de que algunos de los fragmentos aparecieran también por encima de los restos óseos, nos permite suponer que bien pudieran ser los restos de grandes vasijas que pudieron haberse utilizado para introducir los restos.

\section{El enterramiento}

Se produjo en el centro de la fosa, a unos 18 centímetros del fondo, por debajo de los restos óseos aparecía una importante cantidad de fragmentos cerámicos que no sabemos si sirvieron de "cama" o aislante o, como parece más probable, pertenecían a grandes contenedores en los que se introdujeron los restos óseos pues algunos de los fragmentos cerámicos se encontraban por encima de dichos restos. A diferencia de las otras inhumaciones exhumadas, ésta no se encontraba en posición anatómica total sino que los huesos aparecían desmembrados, conservando cada una de las partes su conexión anatómica. La columna vertebral conectaba con la pelvis en su extremo final y con la cabeza en la parte alta, si bien ésta aparecía en posición forzada, doblada hacia atrás, con el occipital tocando la pelvis y mirando hacia el norte. En la zona Este apareció un conjunto de costillas, mientras que en el lado Sur de la fosa se localizó el brazo derecho con su clavícula y en el Noroeste se encontró el fémur izquierdo y sobre él, el pie en conexión anatómica con su tibia y peroné y, en una zona muy próxima, la otra pierna de la que sólo se conservaba tibia y peroné. Entre los restos, muy desechos, había parte del brazo izquierdo. Sobre algunos de estos huesos y los fragmentos cerámicos que se encontraban en contacto con ellos, se colocaron grandes piedras, destacando el tamaño del bloque que cubria la zona de las extremidades inferiores.

Frente a los demás enterramientos choca el desmembramiento sufrido por esto restos cuya mala conservación no ha permitido comprobar si existieron indicios de descuartizamiento provocado por cortes, golpes u otro medio. Por otra parte, la mala conservación del conjunto por la presión de las grandes piedras y su proximidad al nivel de superficie, nos impide conocer su colocación originaria, sin embargo, no resultaría imposible que nos encontremos ante la deposición de los restos desmembrados en varios recipientes (posiblemente tres), destruidos después por la colocación de grandes piedras o, incluso, por el lanzamiento de dichas piedras. 
Los restos corresponden a un varón, joven cuya edad se ha estimado entre 20 y 25 afios, su mal estado conservación ha dificultado obtener datos sobre posibles patologías o traumatismos, así como de su ralla.

\section{El contenido de la fosa}

La subestructura apareció colmatada por dos niveles bien diferenciados el más profundo comprendido entre los -58 y los -30 centímetros con tierras sueltas de tonalidad oscura y textura de grano grueso, entre las que aparecian las grandes piedras, abundantes fragmentos de cerámica de gran tamaño y los restos óseos humanos y la cota comprendida entre -30 y 0 centímetros con tierras de color negro, grano y textura medios y escasa cantidad de material arqueológico.

Los bloques líticos existentes sobre la inhumación correspondían a piedras obtenidas en la propia terraza del río ya que son nódulos de sílex y cuarciras a excepción de una piedra de granito perteneciente a un molino amortizado. La industria lítica se teduce a un elemento de hoz realizado sobre lasca ancha y a una lámina (fig. 10 números 8 y 9).

Más abundantes eran los restos cerámicos ya que el número de fragmentos recogidos asciende a 215 de los que sólo 34 aparecieron en el primer nivel (entre 0 y -30 centímetros) mientras que los 181 restantes se recogieron en el segundo (entre -30 y -58 centímetros), algunos de los cuales eran, además, de gran ramaño. Las características formales y ornamentales de esta cerámica no son demasiado significativas ya que corresponden en su totalidad a recipientes comunes, algunos de los cuales son de gran volumen pues alcanzan un diámetro de boca en torno al medio metro. Concretamente los elementos decorativos de estas grandes vasijas se reducen a mamelones plásticos y a algunas impresiones en los labios, no muy abundantes, estas ornamentaciones se complementan con ciertos acabados de las paredes que, en ocasiones, patecen tener también función decorativa. Los acabados más frecuentes son series de digitaciones creando acanalados paralelos que recorren una parte de la superficie, existen también cepillados o escobillados formando haces de someras incisiones de direcciones diversas (Figura 10, números 5 y 7 y lámina IV, $a, b$ y $c$ ).

Tanto las formas como las ornamentaciones y acabados de los recipientes recuperados en esta fosa son poco significativos no pudiéndose utilizar como criterio de identificación cultural. Unicamente podemos señalar que el cepillado o escobiliado es un tratamiento muy popular durante el Hierro I, aunque no exclusivo de ese momento. Por ello el único indicador que poseemos son los materiales de los "fondos" aparecidos en la zona donde se ubica este enterramiento que, en su mayoría, pertenecen a una facies Protocogotas por lo que, inicialmente, lo englobamos dentro del mismo marco cultural que el resto de los enterramientos.

Otros restos humanos: (PR-03 del estudio antropológico)

(Lámina III, d).

A falta de estudiar todo el material b́seo recuperado en el yacimiento y de realizar su correcta identificación y valoración, tenemos que hacer referencia a la existencia de, al menos, una mandíbula humana aparecida en el fondo 35 de la cuadrícula 29, junto con una importante cantidad de huesos animales y algunos fragmentos cerámicos del Horizonte Cogotas I. Sus características hacen pensar que pertenecieron a un varón joven, de entre 18 y 24 años de edad. 
La presencia de restos humanos de escasas proporciones incluidos dentro de fosas que parecen tener, en su destino final, la función de basureto, no es una novedad en hábitats de "fondos de cabaña" del Horizonte Cogotas I de la región de Madrid, según se desprende de los testimonios que han aportado los yacimientos del Arenero de Soto (Martínez Navarrere, Ma I. y Mendez, A. 1983) y El Negralejo (Blasco, $\mathrm{M}^{2} \mathrm{C}$., 1983). Se trata de unas evidencias que presentan una dificil explicación ya que no podemos saber si se trata de restos a los que hay que dar una explicación única o múltiple, pudiendo proceder, entre otras causas, de la limpieza de zonas donde los cadáveres pudieron estar expuestos, de inhumaciones secundaria, intencionadamente depositadas en pequeñas porciones, de ampuraciones, $o$ incluso de comidas rituales.

Sea lo que fuere, la reiteración de estos restos humanos son un dato de interés que deben de ser tenidos en cuenta a la hora de estudiar el mundo funerario y ritual de la Edad del Bronce para lo que contamos con tan escasos testimonios.

\section{VALORACION GLOBAL}

Los enterramientos que acabamos de describir fueron localizados en el mencionado yacimiento del Caserío de Perales del Río (Getafe, Madrid) que se encuentra situado en la cuenca baja del río Manzanares, sobre la terraza inferior a sólo unos 5 metros de la vega del río la cual domina visualmente. Su excavación ha permitido conocer uno de los más importantes conjuntos arqueológicos de la Edad del Bronce del valle del Tajo y, más concretamente de las Facies Protocogotas y Cogotas I, ya que en sus casi 5 hectáreas se han podido aislar, con bastante claridad, al menos tres momentos de ocupación: Uno de cerámicas lisas o con escasas decoraciones en espina de pescado que podría pertenecer al Bronce antiguo; el segundo momento corresponde a una etapa Protocogotas I mury nítida, se trata de la ocupación más amplia y, por tanto, la que más documentación ha brindado, ocupa unas tres hectáreas y a ella posiblemente pertenecen todos los enterramientos que estudiamos en este trabajo; la tercera fase de ocupación del lugar se identifica con un momento final de Cogotas I con abundantes cerámicas decoradas, entre otras técnicas, con boquique y excisión y en las que son frecuentes las incrustaciones de pigmentos rojos.

En el momento de la excavación había desaparecido el suelo de ocupación conservándose únicamente una gran cantidad de "hoyos" o "fosas" excavados en el subsuelo repartidas de forma muy irregular, las cuales encerraban la totalidad del material mueble arqueológico. El contenido de las más de quinientas "fosas" excavadas era muy desigual, así como la forma en la que se encontraban los restos encertados en ellas, ya que mientras en algunos casos no había más que pequeños fragmentos de cerámicas, huesos y sílex, en otras encontramos auténticos depósitos intencionados y cuidadamente dejados, bien como ofrenda, que nunca se pensó en recuperar, bien como escondrijo o almacén de determinados ensetes que teóricamente deberían de ser reutilizados en sucesivos estacionamientos. En el primer caso es posible que haya que incluir los restos de animales jóvenes cuidadosamente depositados, mientras que en el segundo se encuentran las piedras de molinos guardadas en el fondo de algunos hoyos, a veces agrupadas de dos o de tres en tres.

En el momento actual estamos trabajando en el estudio individualizado del contenido de estos "hoyos" así como en su disposición espacial y en las relaciones de tamatios y formas con el fin de poder llegar a reconstruir las características del establecimiento habitacional y a determinar, si ello es posible, la existencia de espacios dedicados a determinados usos domésticos o industriales. De 
entre este conjunto de varios centenares de fosas u hoyos destacan los cinco en los que se practicaron enterramientos humanos, estas fosas de inhumación se localizaron en diferentes puntos del habitat, en espacios en los que existían otros hoyos de contenido muy distinto, posiblemente relacionado con los desechos domésticos.

El mayor problema con el que nos encontramos es el de discernir qué hoyos de entre los más próximos a los enterramientos, fueron efectivamente contemporáneos suyos, es decir, cuáles fueron realizados y usados por el mismo grupo que practicó el enterramiento. Con este dato tendríamos la posibilidad de conocer si los enterramientos se efectuaton junto a las propias viviendas, en su subsuelo o, por el contrario, en puntos algo alejados de los lugares en los que se realizaban los quehaceres domésticos. Al menos, lo que sí parece clato es que se localizaban en puntos muy próximos a los hábitars, seguramente, dentro de su propio espacio, tal como ocurre entre otros grupos del Bronce Peninsular y, más concretamente, de la Meseta, según se desprende de los datos que nos han facilitado yacimientos como el de La Loma del Lomo de Cogolludo (Valiente, J. 1987 a y b) o algunas de las Motillas (Nájera, T. y otros, 1979) y poblados de altura de la Mancha (Nieto, G. y Sanchez Meseguer, J., 1980).

Sin embargo los paralelos que más nos interesan son los que existen con yacimientos de los Horizontes Protocogotas y Cogotas I en los cuales se inscribe el yacimiento que comentamos. Entre estos grupos las inhumaciones se realizan también en los espacios domésticos o en sus proximidades tal como lo han evidenciado los yacimientos de San Román de la Hornija (Delibes G., 1978) y Los Tolmos de Caracena (Jimeno, A., 1984 y Jimeno, A. y Fernández Moreno, J. J., 1991), en fosas muy similares a las que se utilizan como subestructuras de actividades domésticas, aunque es claro que no son éstos los únicos tipos de enterramientos ya que no es infrecuente la reurilización de monumentos megalíticos o el empleo de cuevas sepulcrales (Esparza, 1990).

Dentro del plano general del yacimiento (Figura 1 y Lámina I, a), cuya extensión completa no ha sido posible reconstruir debido a estar cortado en su zona Sur por la Carretera de Madrid a San Martín de la Vega y a haber sido parcialmente arrasado en su zona Oeste por un antiguo arenero y en su zona Este por una urbanización, los enterramientos aparecen agrupados en la zona Este donde se localizan cuatro de ellos, mientras que el quinto se encuentra en el átea noreste; en este sentido, la falta de excavaciones en extención en yacimientos similares nos impide realizar contrastaciones. Por otra parte, la imposibilidad de aislar las diferentes unidades domésticas y las áreas de actividad industrial por falta de arquitecturas, supone un inconveniente más para relacionar estos enterramientos con zonas concretas del poblado. A ello se suma la dificultad de diferenciar las estructuras que pertenecen a cada una de los establecimientos, sobre todo, si se tiene en cuenta que algunas de estas ocupaciones pudieron ser de muy escasa duración.

Estos enterramientos presentan algunos aspectos que merecen especial atención, éstos son:

\section{1.- El marco cronológico y cultural}

Desgraciadamente no todos los enterramientos que estudiamos contienen un ajuar suficientemente significativo como para permitir su encuadre temporal, sin embargo las características de los materiales cerámicos de tres de los cinco enterramientos (Fondo 30, cuadrícula 18; Fondo 21, cuadrícula 43 y fondo 23, cuadrícula 31) nos facilitan su inclusion, con bastante seguridad, dentro de la fase Protocogotas. Por el contrario no contamos con materiales significativos en los otros 
dos enterramientos y sólo podemos constatar que se encuentran en unas zonas donde la mayoria de los fondos son también de la misma fase Protocogotas, si bien se trata de un argumento muy poco definitivo, ya que podrian encontrarse algo alejados de los fondos utilizados como habitación por el grupo al que pertenecieron estos enterramientos.

A la luz de los datos de este yacimiento, bastante coincidentes con los de otras zonas, todo parece indicar que la inhumación en fosa, en posición contraída, dentro del ámbito doméstico, sin afecrar a la totalidad de la población, es relativamente frecuente en la fase Protocogotas mientras que tiende a enrarecerse en el horizonte de plenitud de Cogotas I. Este hecho, que parece común en el ámbito nuclear del Horizonte Cogotas I, es decir, a ambos lados del Sistema Central, encaja bien con el panorama funerario de la Edad del Bronce en otros círculos peninsulares que durante el Bronce medio ofrecen abundantes muestras de enterramientos, entareciéndose notablemente a partir del Bronce Final.

Provisionalmente la fase Protocogotas se ha fechado en torno a los siglos XVI-XIV a.C. aun cuando no contamos, por el momento, con fechas absolutas para el yacimiento que nos ocupa, esta datación propuesta para otros establecimientos resulta perfectamente aceptable para el hábitat y los enterramientos protocogotas de Perales del Río.

\section{0: a.- Las estructuras}

Como antes apuntamos, se trata de fosas u "hoyos" de motfología y dimensiones similares a las que aparecen en todo el establecimiento utilizadas para fines diversos (almacenamiento, ofrendas, basureros, silos, etc.), ninguna de ellas presenta indicios de revestimiento o preparación especial "in situ", aunque en algunos casos se han recogido restos de manteado o tapial que pueden haberse desprendido de las paredes. Además hay un dato que resulta de interés: mientras los enterramientos que no tienen lecho o recipiente de cerámica que los aísla, se encuentran en fondos que alcanzan los 100 centímetros de profundidad y, por tanto, llegan hasta un nivel de arenas muy permeable que facilita el drenaje impidiendo el encharcamiento, las inhumaciones de los dos niños y del individuo desconyuntado se han realizado en fosas de menor profundidad ( 50 y 80 centímetros tespectivamente) alcanzando un estrato de arcilla mucho más impermeable circunstancia que, unida a la menor profundidad con respecto a la superficie, es causa de un deficiente aislamiento suplido sólo por la utilización de cerámicas como envase o solado.

Otro dato a tener en cuenta es el diámetro de la boca de estas fosas que oscila entre 120 y 200 centímetros, una dimensión que permite el acceso de una persona hasta el nivel de depósito de la inhumación y, por tanto, facilita su cuidadosa colocación, incluso en los dos casos en que se ha ubicado en un covacho abierto en una zona de las paredes de la fosa.

En cuanto a la morfología de las fosas podemos establecer dos tipos: el correspondiente a los hoyos simples y el que presenta la adición de un covacho excavado en un punto de la zona baja de las paredes. En el ptimer caso las deposiciones se han practicado en el centro de la misma base del hoyo, bajando los restos del difunto directamente desde la superficie en el caso de los fondos poco profundos, y por medio de cuerdas o lienzos, cuando se trata de fosas de más de un metro de altura. En el segundo tipo, sin embargo, parece necesario colocar el cadáver en el cubículo abierto para tal fin, descendiendo hasta la misma base de la fosa para desde alli, arrimarlo al pequeño covacho. 


\section{b.- El relleno y la cubrición de la fosa}

Con respecto a la cubrición, encontramos dos fórmulas:

a) Relleno de la fosa con tierras procedentes de la superficie entre las que aparecen materiales amorrizados $\mathrm{y}$ b) sellado con tierras y/o piedras cuidadosamente seleccionadas. La fórmula de colocar grandes piedras se ha empleado para cerrar el covacho donde se practicó el enterramiento correspondiente al fondo 21 de la cuadrícula 43 (figura 3). Pero el caso más llamativo es el del enterramiento del fondo 11 de la cuadrícula 43 (figura 8,1 ) donde el cadáver se situó en el fondo de la fosa, desplazado hacia el noroeste colocándose dos grandes piedras de yeso junto a la cadera y la cara, después se cubrió todo con un nivel de limo verdoso bastante fino de unos 15 centímetros de espesor; sobre esta capa, pero centrada en la planta de la fosa, se dispuso una gran acumulación de piedras que quedaron sepultadas por la colmatación del fondo con tierras procedentes de la superficie del yacimiento. Coronando el fondo y destacando en la superficie se colocó un segundo enlosado que posiblemente sirvió de señalización visual. Aunque no hemos encontrado otras señalizaciones en el resto de los enterramientos no descartamos la posibilidad de que existieran y que hayan desaparecido por el arrasamiento del suelo de ocupación.

En el resto de lo enterramientos, tras la deposición del cadáver, se procedió a colmatar la fosa con tierras procedentes de la superficie que contenían restos de materiales cerámicos y líticos así como desechos de comida. Desgraciadamente resulta dificil saber si existib intencionalidad en la intrusión de algún material concreto, aunque sospechamos que pudo haber tal intención en el caso de las piedras de granito, de procedencia foránea pero presentes en todos los enterramientos.

\section{$3^{\circ}$.- Los ritos de enterramiento}

A pesar de existir una aparente homogeneidad hay una considerable variabilidad en determinados aspectos como son la orientación del difunto, el ajuar, la propia fórmula de deposición, o el número de inhumados dentro de cada estructura, caracteristicas que hasta el momento permanecían prácticamente inéditas dada la escasez de enterramientos procedentes de excavaciones sistemáticas.

Los aspectos comunes, tanto a estos enterramientos que comentamos como a otros procedentes de otras zonas de la Meseta e inscritos en el marco cultural del Horizonte Protocogotas o Cogotas I, son la práctica de la inhumación, la colocación de los cadáveres en posición fetal y su deposición dentro de fosas abiertas directamente en el subsuelo. Fuera de estos rasgos tan genéricos no hay más denominadores comunes aun cuando, existen orras pautas relativamente frecuentes.

Centrándonos en los enterramientos que estudiamos interesa hacer referencia a los aspectos diferenciadores de una o varias inhumaciones:

a.- El número de enterrados dentro de cada estructura

Como hemos visto, cuatro de los cinco enterramientos corresponden a inhumaciones individuales, pero la quinta acoge dos inhumaciones, concretamente a los dos únicos individuos infantiles. Sin embargo no se trata de un hecho excepcional, ya que no son raros los enterramientos dobles o triples como es el caso de San Román de la Hornija (Delibes, G., 1978) y Los Tolmos (Jimeno, A., 1984). En la mayoría de estas inhumaciones múltiples aparece algún individuo infantil, pero lo que ya no resulta tan común es que los niños se encuentren sin el acompañamiento de un adulto como es el caso de Perales del Río.

b.- La posición y orientación de los cuerpo 
Ya hemos apuntado que, a excepción del cuerpo descoyuntado, los demás han sido colocados en posición fetal, con las piernas bastante contraídas y con una o las dos manos, apoyadas en el mentón, mientras que la otra, o se coloca sobre el abdomen, o sujeta la muneca del brazo contrario. En cambio, no se ha observado ninguna pauta común en cuanto a la orientación de los restos, colocados indistintamente en el eje norte-sur o este-oeste y con los pies y cabeza en las más diversas direcciones; así mismo la deposición se practica indistintamente sobre el lado izquierdo o derecho mirando hacia el frente, saivo en un caso que presenta la cabeza vuelta hacia arriba.

Mención aparte merece la inhumación de unos restos desconyuntados cuyo depósito parece estar claramente individualizado en, al menos cuatro lotes diferentes (Figura 9, 1 y 2); por un lado cabeza, tronco y pelvis en posición muy forzada, con la parte posterior del cráneo tocando la pelvis; por otro lado las costillas; en un tercer apartado uno de los brazos en conexión anatómica y restos del otro btazo en muy mal estado de conservación y en un cuarto conjunto piernas y pies uno de los cuales conservaba su conexión.

Resulta dificil interpretar esta deposición por su mal estado de conservación y la falta de paralelos claros dentro de la Prehistoria teciente peninsular. El hecho es que desconocemos si estamos ante un caso de enterramiento secundario al que se le han cortado los restos de tendones y piel que quedaban para proceder al descoyuntamiento de los huesos 0 , por el contrario, esta práctica se ha levado a cabo para realizar la primera inhumación de los restos de manera parcializada; desgraciadamente la mala conservación de los extremos distales de los huesos largos impide observat la posible existencia de cortes o raspaduras.

c.- El ajuar

En, al menos, dos enterramientos no se ha colocado nada de ajuar, ni en contacto con el difunto, ni en orros puntos de la fosa, en un tercer enterramiento se ha colocado una cazuela carenada a la altura del temporal y es probable que haya que asociar con este mismo enterramiento el contenido de una fosa localizada a tan sólo una treintena de centímetros de la destinada a la inhumación y en al que aparecía una gran cantidad de huesos animales, todavia pendientes de analizar y que pudieron proceder, bien de una comida ritual, bien de un almacenamiento intencionado de viveres destinados a la alimentación del difunto.

Otro es el caso del ajuar asociado a la doble inhumación infantil a los pies de cuyos cuerpos se colocó un perro de tamaño medio, y muy cerca de ellos había una cierta cantidad de fragmentos de varios recipientes, algunos de los cuales estaban completos y otros aparecieron alterados, posiblemente, por la escasa profundidad a la que se encontraban; así mismo se recogió una pesa de telar, además de una cierta cantidad de restos óseos animales.

Más complicada resulta la explicación de los abundantes restos cerámicos que se encontraban junto a los huesos de la inhumación descoyuntada y que corresponden, en su inmensa mayoria, a grandes recipientes con un diámetro de boca de unos 50 centímetros, estos fragmentos aparecieron tanto por debajo como por encima del inhumado lo que puede ser indicio de que fueran utilizados como receptáculos de los propios restos humanos, ya que la disposición en que se encontraban hace poco probable que se trate de ajuares cerámicos o de contenedores de víveres.

Otro dato de interés, en este caso común a la totalidad de los enterramientos, es la presencia de granito en proporciones más o menos grandes. Generalmente son bloques procedentes de molinos amortizados que se encuentran ditectamente asociados a los restos humanos o formando parte del relleno de la fosa. El interés de la incorporación del granito a los enterramientos estriba en la distancia de su fuente de procedencia ya que las afloraciones más próximas se encuentran en el Sistema Central, a unos 40 kilómetros de distancia. Teniendo en cuenta que es el único material 
exótico aparecido en la totalidad de los enterramientos y que también lo hemos encontrado en las dos tumbas campaniformes exhumadas en esta zona, pensamos que debe tener un especial significado, quizás relacionado con la agricultura cerealista.

\section{$4^{\circ}$.- El número de enterramientos y características de los inhumados}

El primer aspecto que interesa destacar es el escaso número de enterramientos localizados sen un hábitat tan amplio, circunstancia que parece indicar que sólo una pequeña parte de la población recibía sepultura dentro del entorno del hábitat sin que sea posible determinar la causa de este hecho ya que no se han documentado, hasta el momento, necrópolis correspondientes a este horizonte cultural, que justifiquen el enterramiento de la mayor parte de la población dentro de determinados espacios más o menos alejados del poblado destinados a este fin. No obstante, sí sabemos que, al menos, algunos de los muertos eran inhumados en cuevas o megalitos con larga tradición funeraria (Esparza 1990, p. 130). Se trata sin embargo de casos muy contados que tampoco parecen representar a una importante parte de la población por lo que queda sin aclarar qué se hacía con la mayoría de los cuerpos de los fallecidos.

Hasta que no dispongamos de nuevos datos tenemos que pensar que, o bien no estaba generalizada la práctica de las inhumaciones, dejándose los cuerpos expuestos a la intemperie, o incinerándose sin dejar ningún rastro. Concretamente para la primera de estas dos hipótesis contamos, en el Horizonte Cogotas I, con la aparición de restos humanos muy fragmentarios asociados a desechos de cocina aunque este indicio nos falta en la fase Protocogotas a la cual parecen asociarse los enterramientos que comentamos.

Igualmente complicado resulta explicar la causa de los individuos seleccionados para las inhumaciones ya que si tenemos en cuenta la muestra obtenida en el yacimiento de Perales del Río nos encontramos con dos individuos adultos, dos juveniles y dos niños de los que dos son mujeres, dos varones y en dos no se puede determinar el sexo debido a su corta edad. Por otra parte, tampoco los ajuares (inexistentes o muy escuetos) nos permiten hablar de individuos de cierto status o capacidad económica ni de su actividad económica. Esta falta de indicios significativos sobre el papel que los enterrados pudieron desempeñar nos impide obtener conclusiones de cualquier tipo.

Un caso singular es el del individuo descoyuntado, ya que no sabemos si su desmembramiento se produjo post o ante mortem, ni existen datos tampoco para relacionarlo con dererminados ritos funerarios, ello nos impide poderlo poner en relación con el enterramiento del mismo horizonte Protocogotas localizado en (Palencia) (Strato, 1992) donde el inhumado aparece con las manos a la espalda, quizá por llevarlas atadas, fruto de la pérdida de libertad.

\section{$5^{\circ}$.- Antecedentes y paralelos}

Uno de los aspectos de mayor interés es el origen de este tipo de enterramientos cuya raiz parece encontrarse en las prácticas campaniformes (Esparza, 1990, p.131 y ss.) de los grupos de la meseta y, más concretamente, para el caso que nos ocupa, contamos con algunos ejemplos campaniformes de la propia región de Madrid, donde hemos comprobado la práctica de depositar las inhumaciones, en posición contraída, en fosas de tamaño y morfología similares a las que comentamos y con ajuares muy sencillos constituídos exclusivamente por vasos cerámicos.

En las proximidades del Caserío de Perales a poco más de un kilómetro, hemos localizado dos enterramientos campaniformes con inhumaciones individuales en fosa, colocadas en decúbito late- 
ral contraídas cuyos paralelos con los enterramientos Protocogotas resultan verdaderamente significativos. Entre otras circunstancias, hemos advertido su cercanía a un pequeño locus de habitación; así mismo hemos podido comprobar la existencia de enlosados señalizando la localización del enterramiento y la existencia de una gran acumulación de piedras rellenando la fosa. Con estas evidencias queda confirmada plenamente la pregunta que se formulaba A. Esparza, sobre si existiría una línea de continuidad entre los enterramientos campaniformes y Cogotas en las campiñas del Jarama y sus afluentes (Esparza, A., 1990 p. 135).

Por otra parte el ritual funerario de Protocogotas no puede ser considerado como un caso aislado, antes bien, las prácticas de enterramiento de este grupo encajan perfectamente con el panorama funerario de la Edad del Bronce Peninsular en el que encontramos pautas muy similares a las observadas por este círculo cultural como es la proximidad de los enterramientos a los lugares de hábitat, la deposición del cuerpo de decúbito lateral contráda, la utilización de fosas individuales o, en todo caso, para dos o tres individuos, las ofrendas de fauna, etc.; sin embargo, resultan también evidentes algunos rasgos especificos como son el menor número de inhumaciones que existen en este círculo frente a aquellos que practican un urbanismo más desarrollado, como el mundo argárico o los poblados de altura de La Mancha, así como la casi inexistencia de ajuares metálicos y la ausencia total de armas, contrastando fuertemente con el mundo del Argar. Posiblemente estamos ante pueblos con un régimen de vida muy distinto $y$, sobre todo, ante concepciones muy diferentes acerca de la muerte.

En todo caso, estos enterramientos de la fase Protocogotas presentan estrechas relaciones con los que practican sus sucesores del Horizonte Cogotas I. quizás el círculo cultural peninsular del Bronce Final del que tenemos más datos sobre el mundo funerario y uno de los últimos círculos inhumadores, antes de la difusión, por toda nuestra geografía, de la práctica de la incineración. 


\section{BIBLIOGRAFIA}

Aubet, M² E., Serna, M² R. Escacena, J. L. y Rutz Dellgado, Mª M., 1983: La Mesa de Setefilla, Lora del Rio (Sevilla). Campaña de 1979. "Excavaciones arqueológicas en España n 122 ". Mínisterio de Cultura. Madrid.

Blasco, $\mathrm{M}^{2} \mathrm{C}$, 1983: "Un nuevo yacimento del Bronce madrileño. El Negralejo, Rivas-Vaciamadrid" Noticiario arqueológico hispdnico, no 17. Madrid, pp. 45-190.

... (1987): "El Bronce Medio y Final". En 130 años de Arqueologia madrileña Madrid, pp. 82-107.

DEuBBES, G., 1978: "Una inhumación triple de la facies Cogotas I en San Román de la Hornija (Valladolid)". Trabajos de Prehistoria, 35. Madrid, pp. 225-250.

ESPARZA, A., 1990: "Sobre el ritual funerario de Cogotas I". Boletin del Seminario de Arte y Arqueologla, LVI. Valladolid, pp. 106-143.

GABBAR, C., 1974: "Descubrimiento de la terraza würmiense en la terraza izquierda del río Manzanares: aportaciones paleodimáticas. Nuevos restos y testimonios del hombre prehisrórico y protohistórico" Estudios Geologicos, XXX, Madrid, pp. 235-252.

JiMENo, A., 1984: Los Tolmos de Caracena (Soria). "Excavaciones Arqueologicas en Espafia", n 134. Madrid.

Jimeno, A. y Fernandez Moreno, J. J., 1991: Los Tolmos de Caracena (Soria). (Campañas 1981 y 1982). Aproximación al Bronce Medio de la Meseta. "Excavaciones arqueológicas en España", $\mathrm{n}^{\circ} 161$, Madrid.

Martinez Navarrete, Ma I y Mendez, A., 1983: "Arenero de Soto. Yacimiento de "fondos de cabaña" del Horizonte Cogotas I". Estudios de Prehistoria y Arqueologia madrileña. Madrid, pp. 183-254.

Najera, T., Molina, F., Torre, F. De ia , Aguado, P. y SaEz, L., I979: “La Motilla del Azuer (Daimiel, Ciudad Real). Campaña de 1976". Noticiario Arqueológico Hispánico, 6. Madrid, pp. 21-50.

Nieto, G. y SANChez MeSeguer, J., 1980: El Cetro de la Encantada Grandtula de Calatrava (Ciudad Real). "Excavaciones Arqueológicas en España", $n^{\circ}$ 113. Madrid.

SanChez Meseguer, J., Fernandez Vega, A. Gaian, C. y Poyato, C.: El Neolitico y al Edad del Bronce en la Región de Madrid. Diputación de Madrid, "Arqueología y Paleoecología, 3".

STRATo, 1992: "Hallazgo de un enterramiento en fosa de la Edad del Bronce". Revista de Arqueologia, $n^{\circ}$ 134, Madrid, p. 56.

VaLiente MaLla, J., 1987: La Loma del Lomo I (Cogolludo, Guadalajara). "Excavaciones arquueológicas en España, $n^{\circ} 152$, Madrid.

... (s.a.) "Enterramientos de zito argárico en la Meseta. El poblado de La Loma del Lomo (Cogolludo,

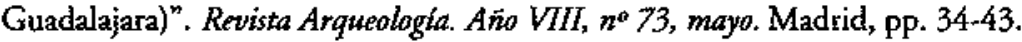




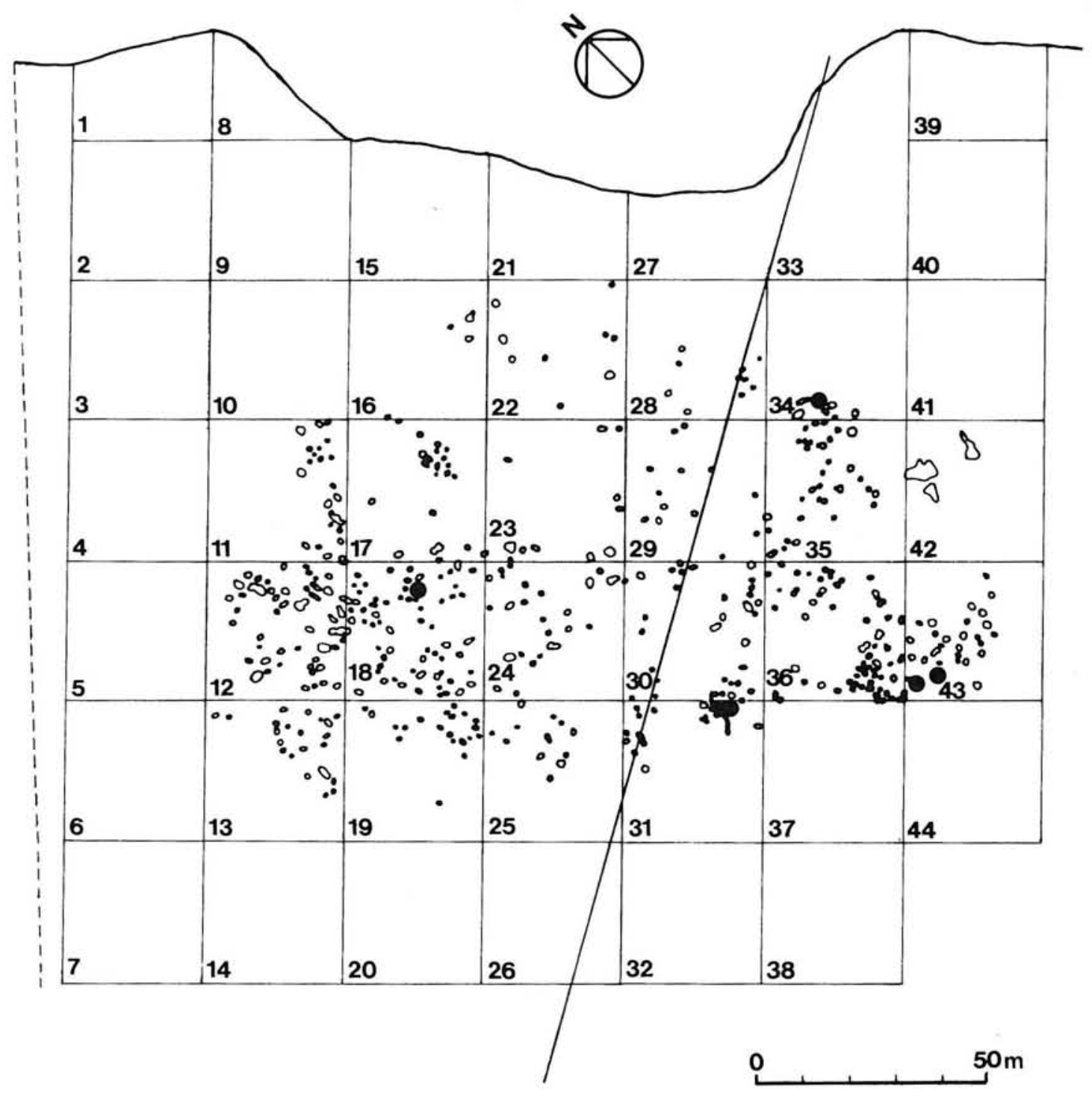

Figura 1.- Plano general del yacimiento del Caserío de Perales. Los puntos negros indican el lugar donde se localizaron los "fondos" con enterramientos. 

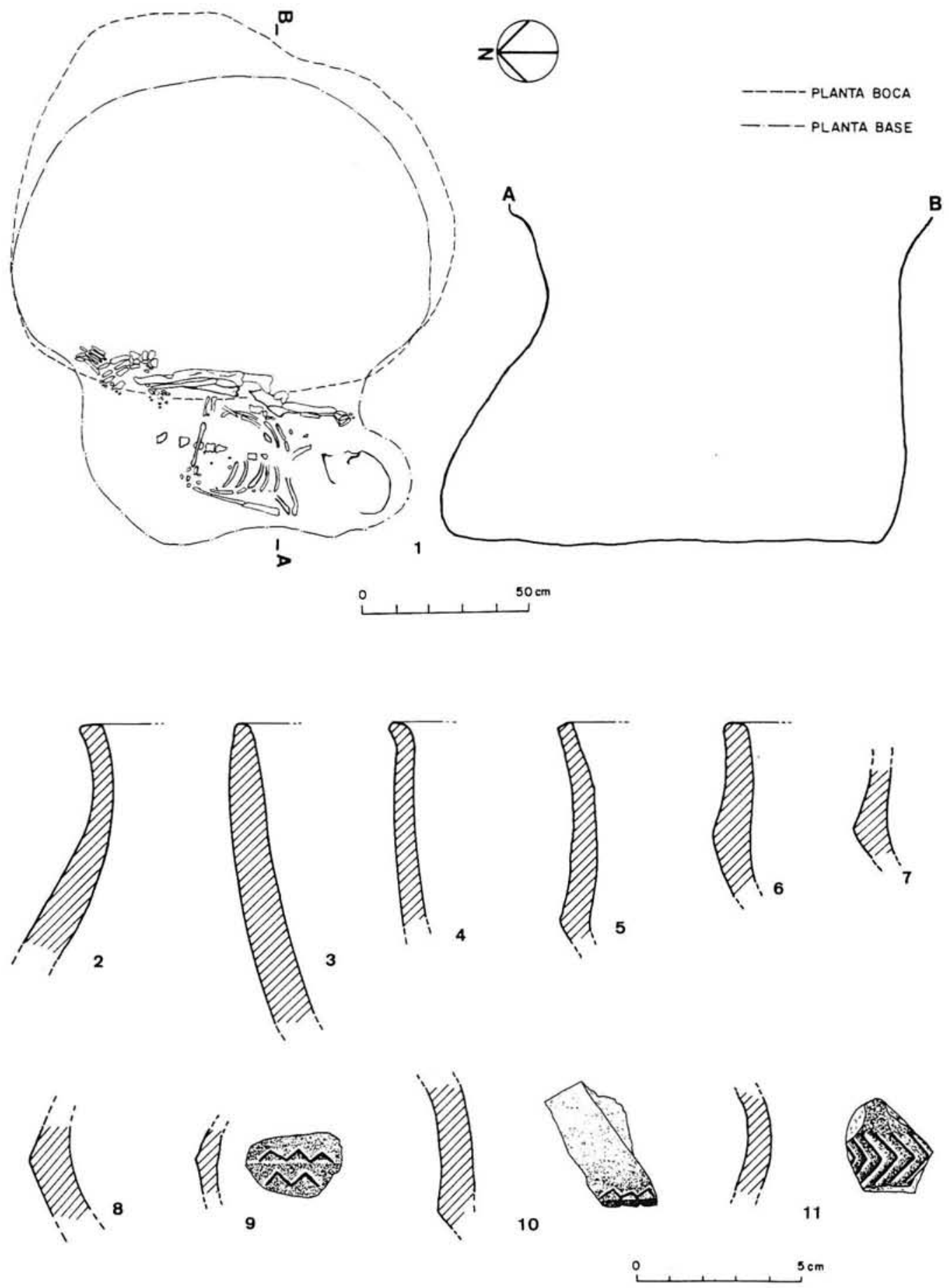

Figura 2.- 1: Planta y sección del enterramiento del fondo 30, cuadrícula 18 (PR-01).- 2 a 10: Algunos fragmentos cerámicos recogidos entre las tierras de relleno de este fondo. 


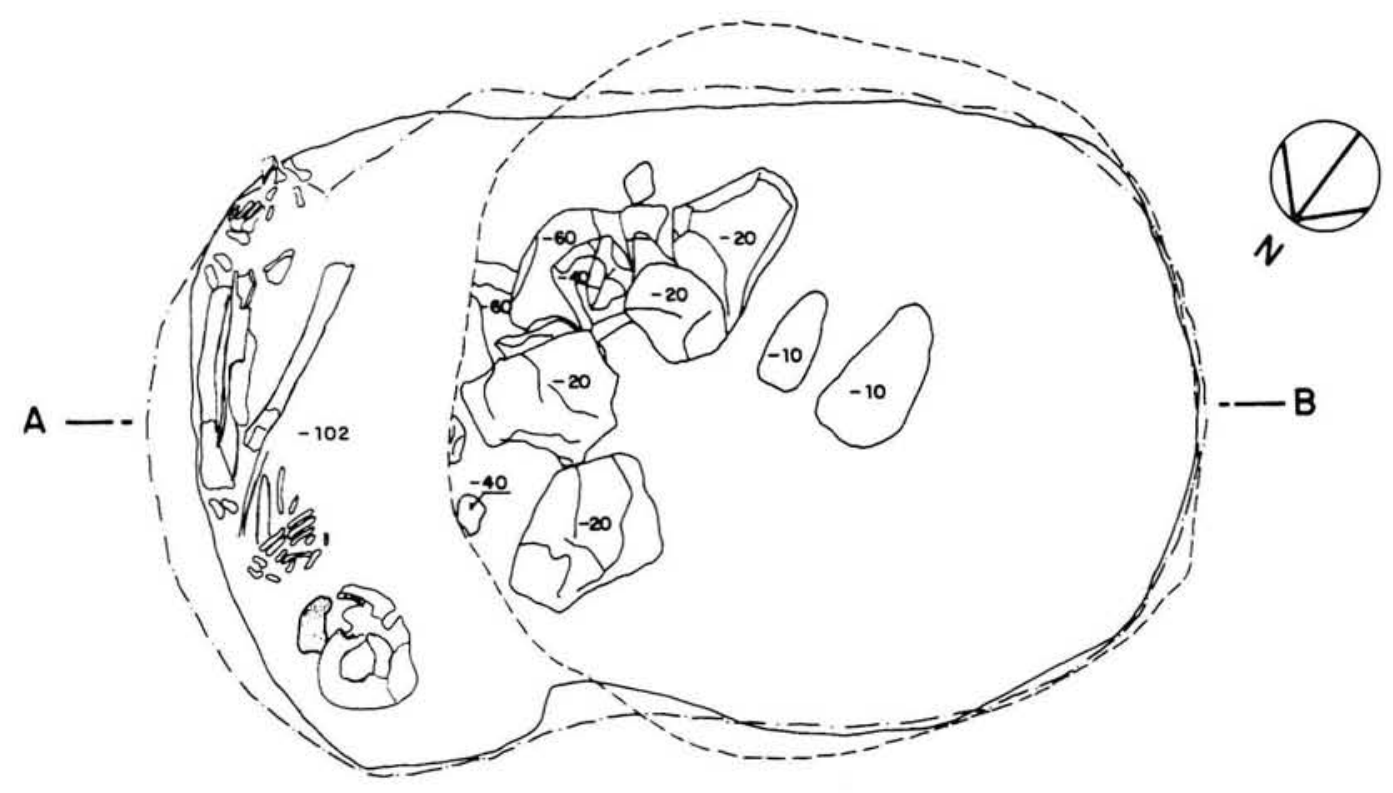

- PLANTA ENTERRAMIENTO
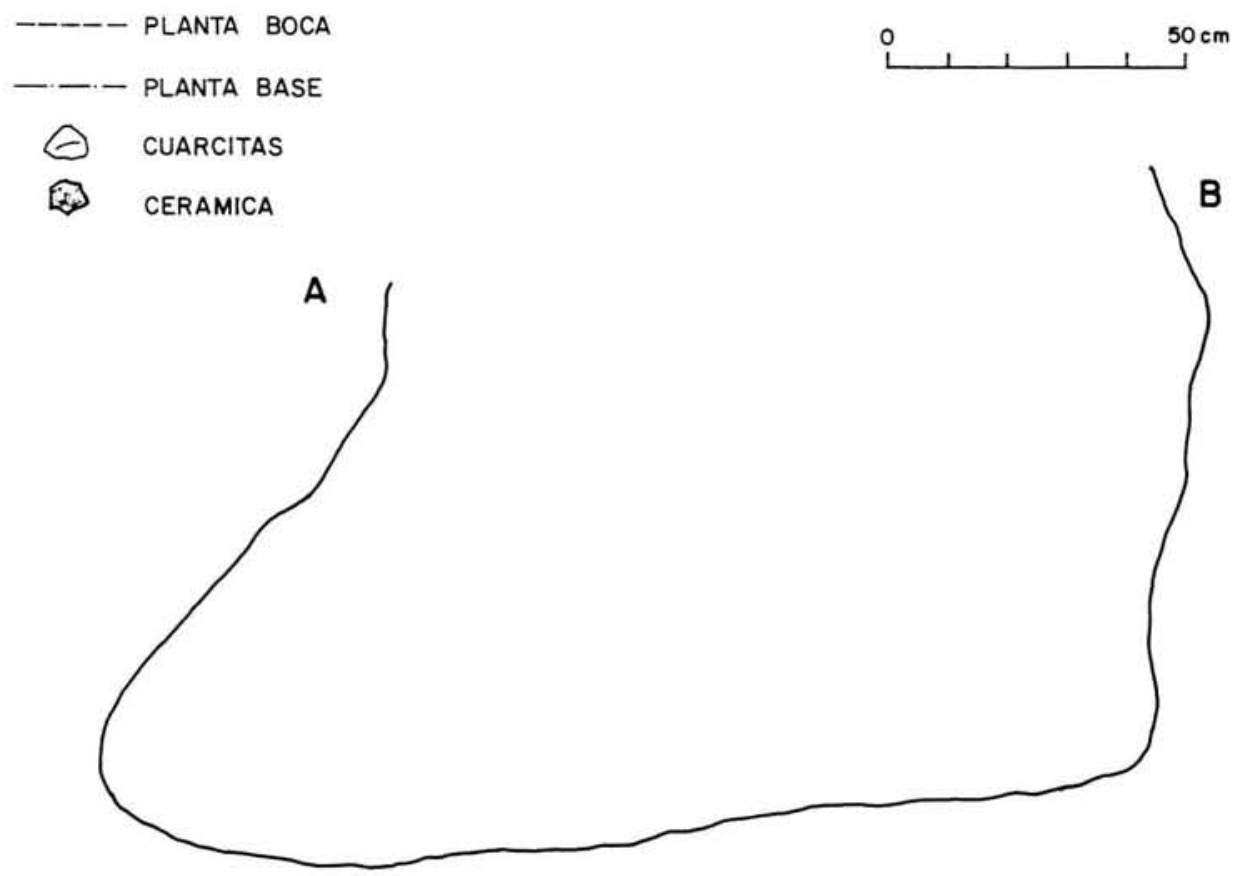

Figura 3.- Planta y sección del enterramiento del fondo 21, cuadrícula 43 (PR-04). 

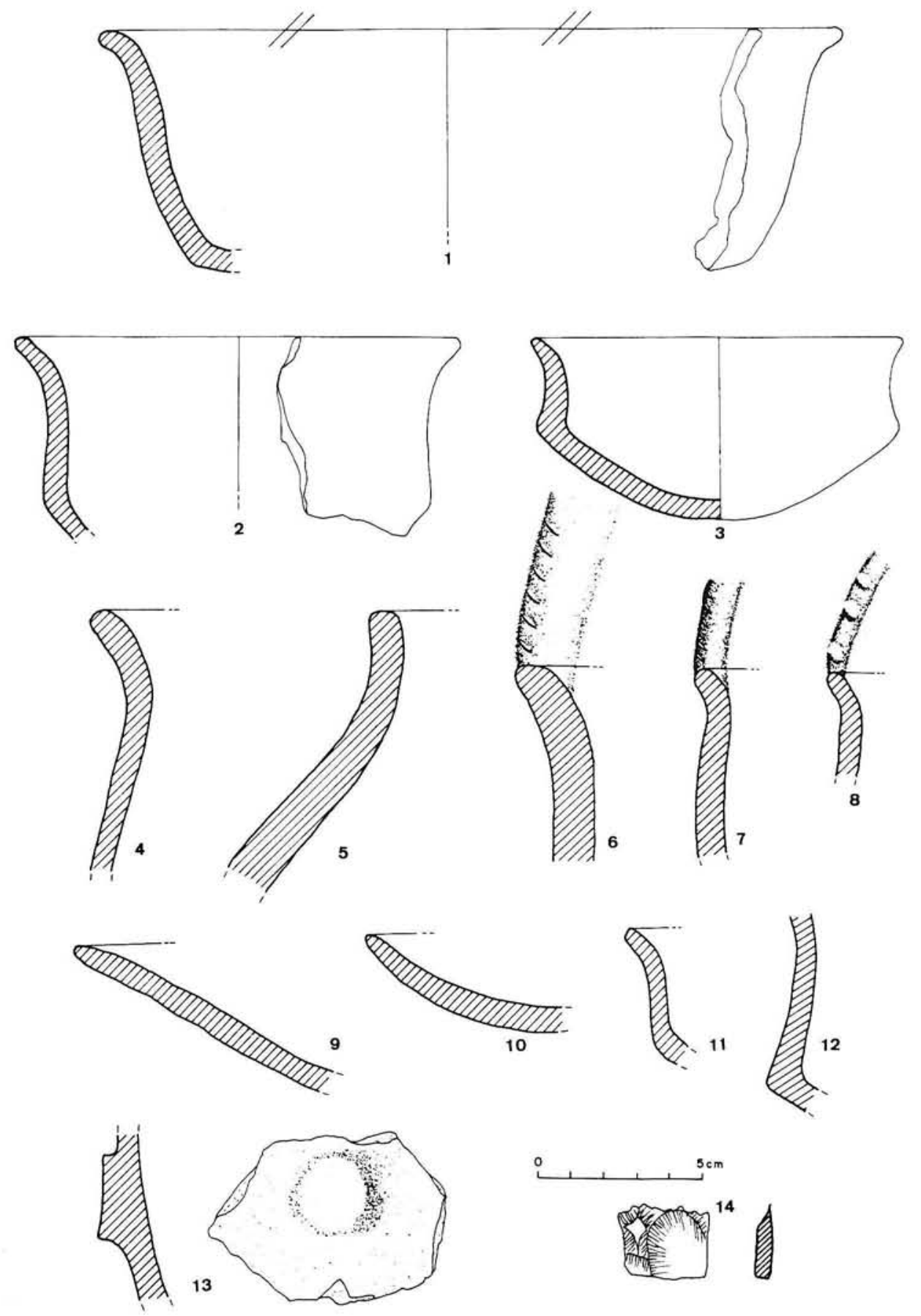

Figura 4.- Números 1,2 y 4 al 14 fragmentos de cerámica y elemento de hoz recogidos entre las tierras de relleno de la fosa de enterramiento: fondo 21, cuadrícula 43. La cazuela correspondiente al número 3 apareció colocada junto al temporal del inhumado. 

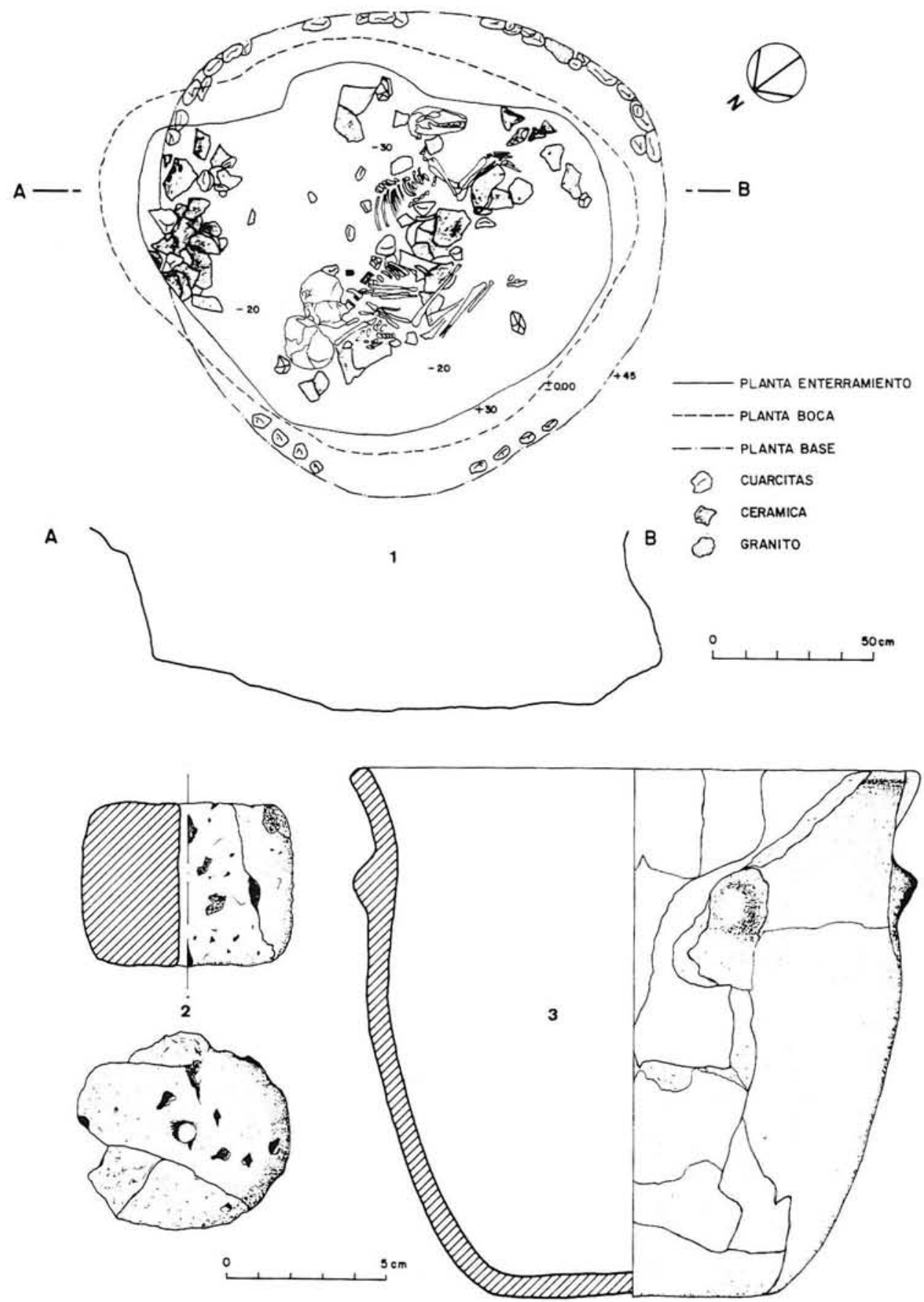

Figura 5.- 1: Planta y sección del doble enterramiento del fondo 23, cuadrícula 31 (PR-05 y PR-06).- 2 y 3: Pesa de telar y recipiente aparecidos entre los materiales concentrados en la zona noreste del fondo. 

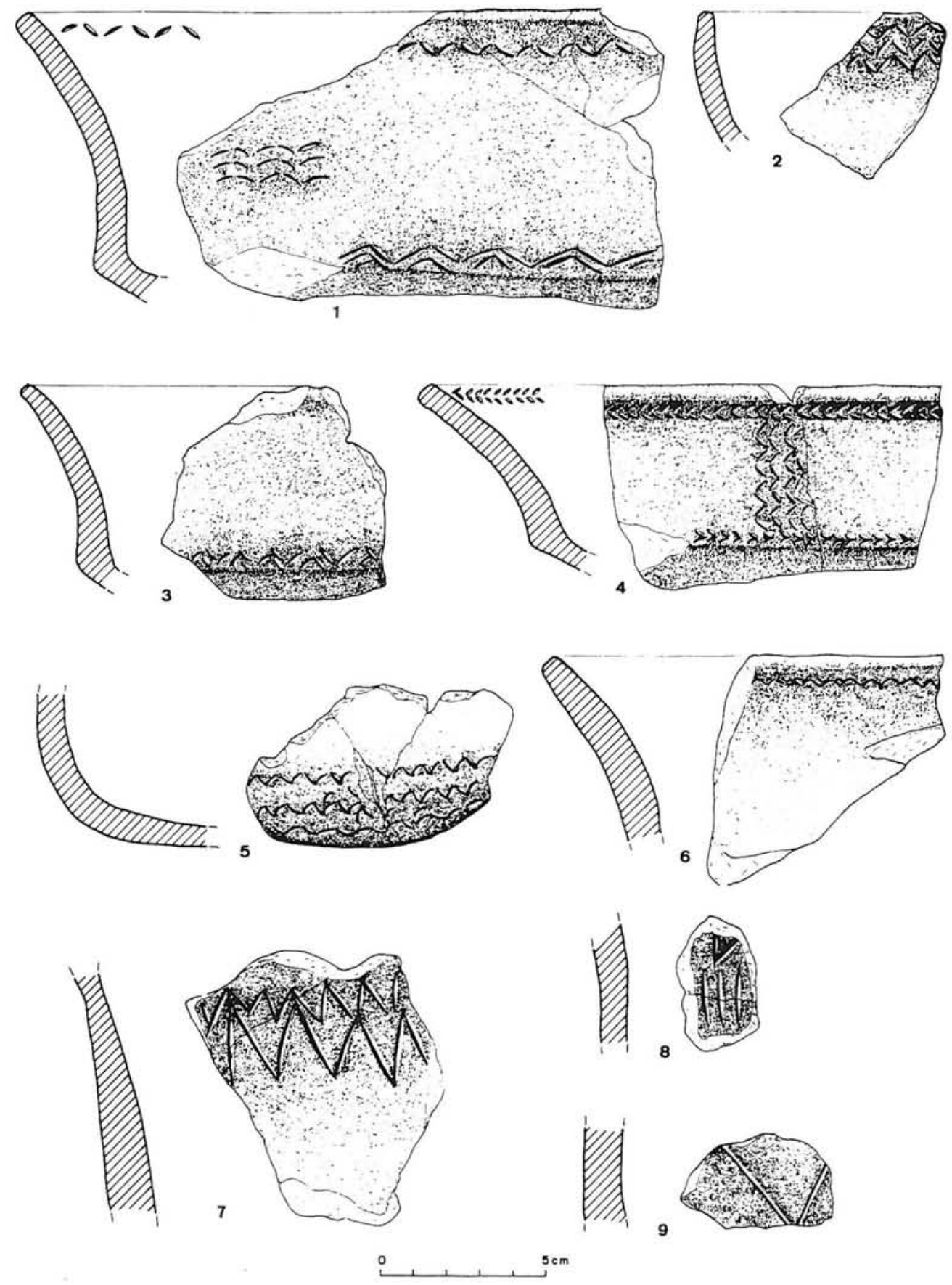

Figura 6.- Algunos de los materiales cerámicos decorados con incisiones con zig-zag y espigas aparecidos en la zona noreste del fondo 23 , cuadrícula 31 . 

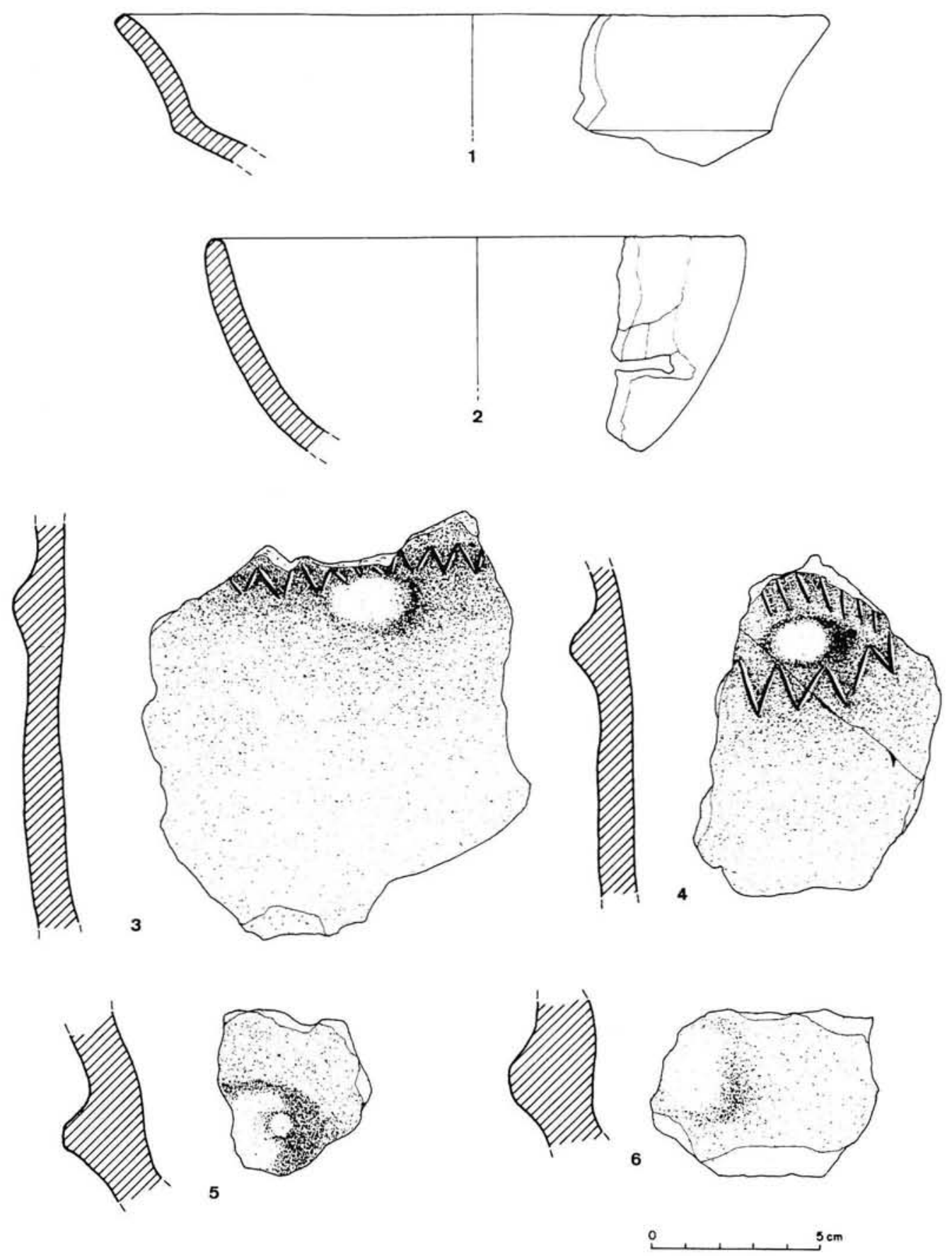

Figura 7.- Selección de materiales cerámicos recuperados en el fondo 23 de la cuadrícula 31. 

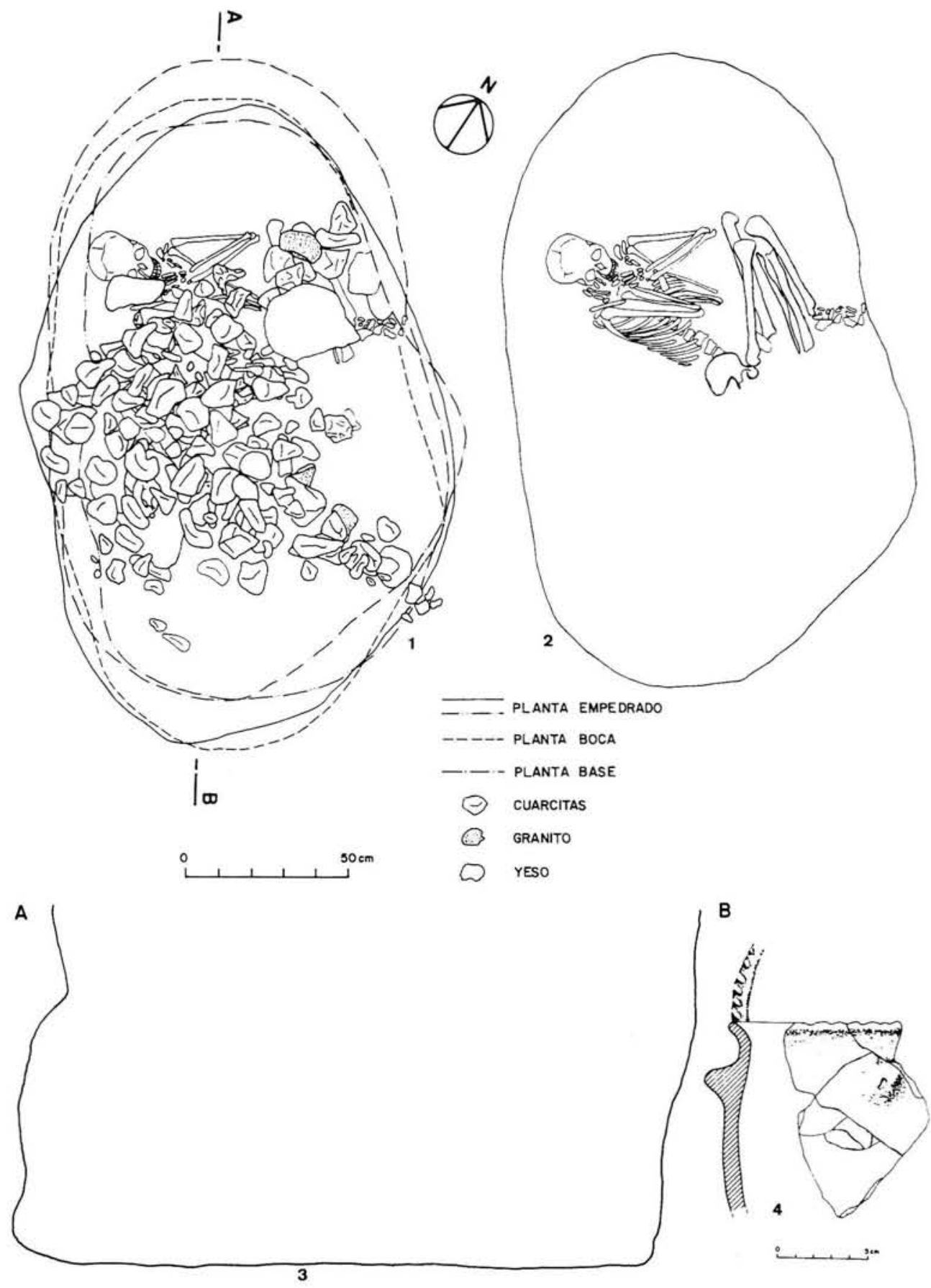

Figura 8.- 1: Planta del enterramiento del fondo 11, cuadrícula 43 (PR-07 del informe antropológico), antes de desmontar la acumulación de piedras.- 2: Planta del plano inferior del mismo enterramiento.- 3 : Sección del mismo fondo.- 4: Unico fragmento de cerámica decorado, recuperado entre las tierras que colmataban la fosa de enterramiento (fondo 11, cuadrícula 43). 

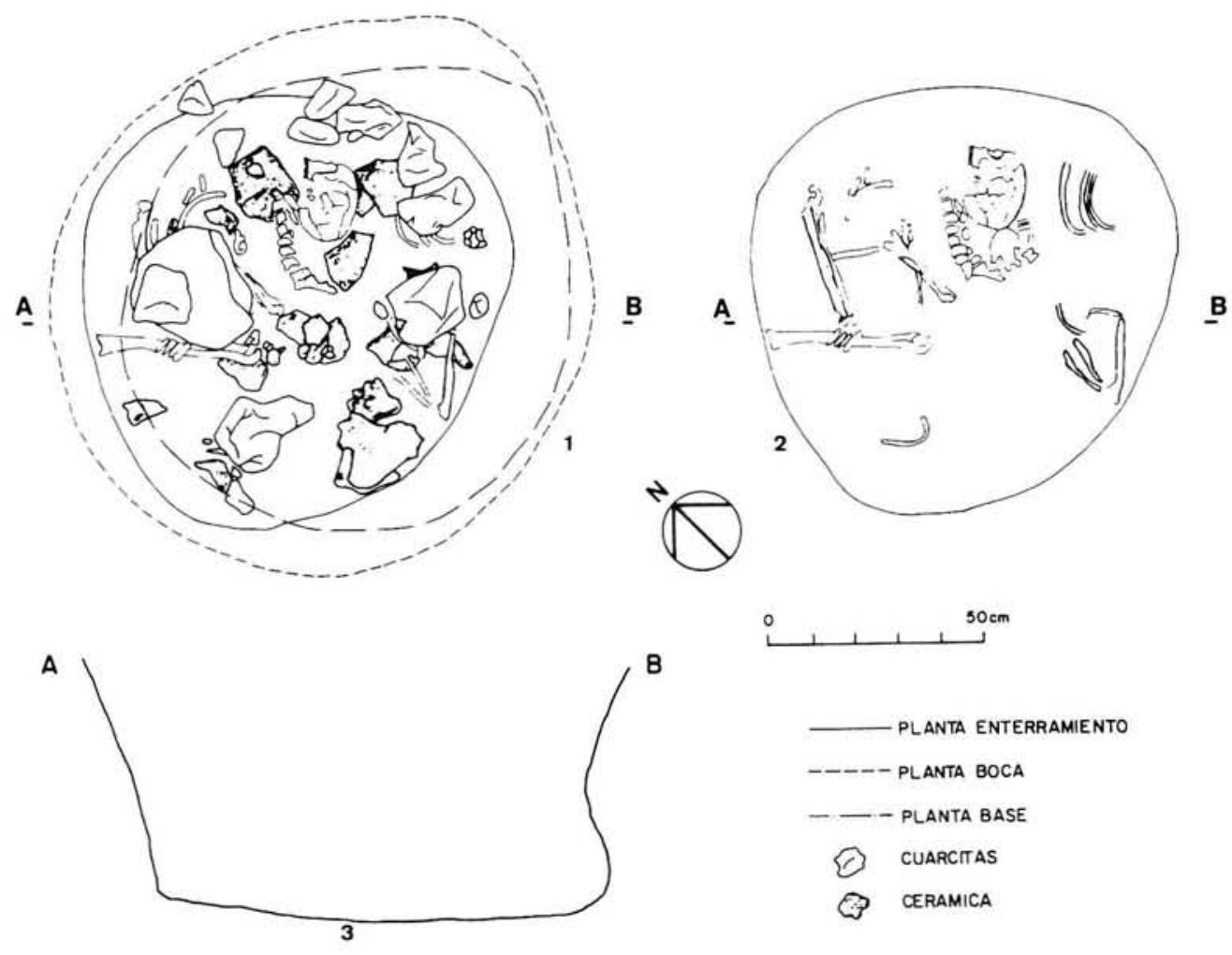

\section{0}
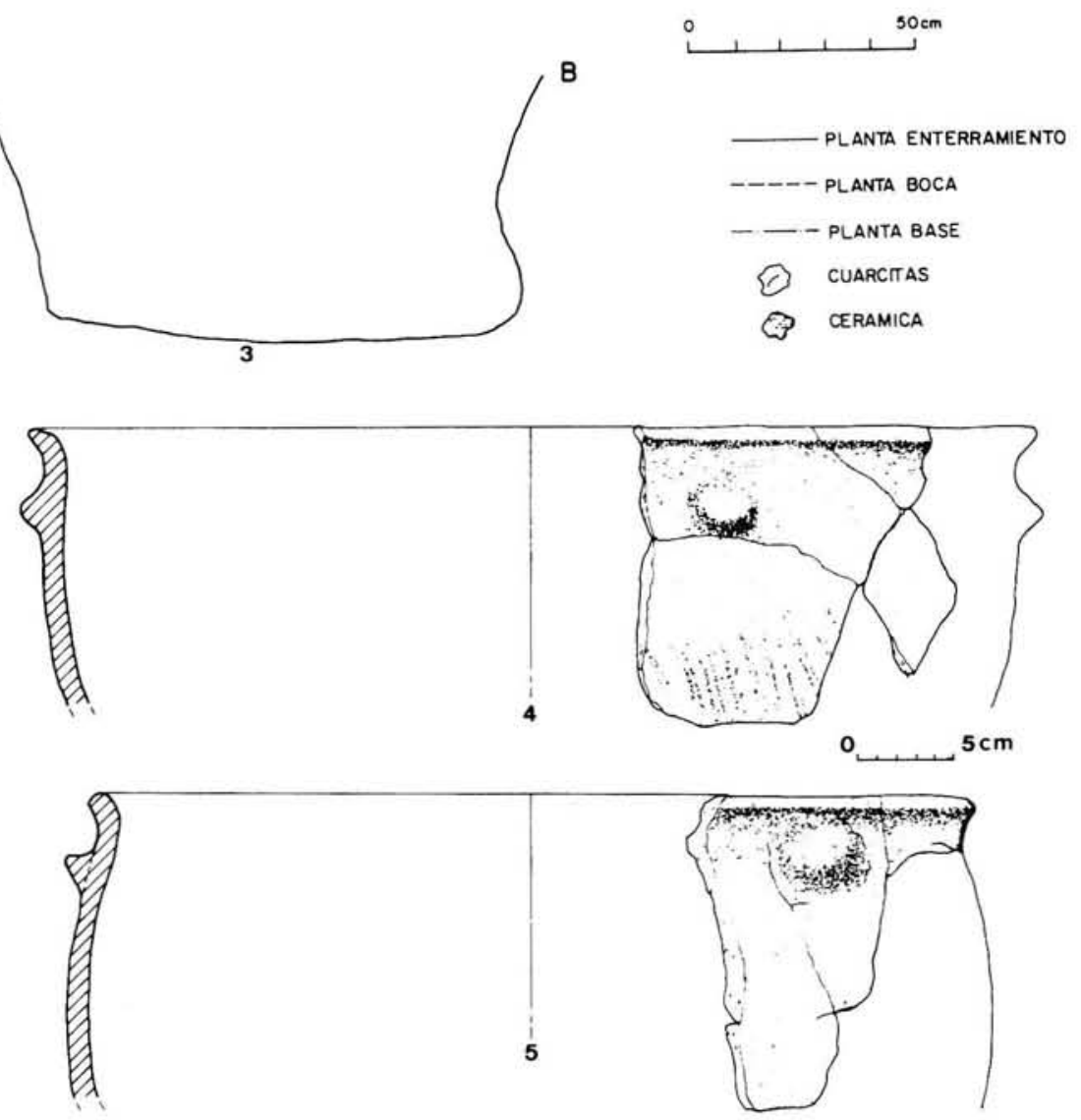

Figura 9.- 1: Planta del enterramiento del fondo 20 de la cuadrícula 34/35 (PR-03 del informe antropológico) antes de retirar los grandes bloques líticos situados sobre los restos humanos.- 2: Planta del mismo enterramiento después de retirar las piedras.- 3: Sección del fondo del mismo enterramiento.- 4 y 5: Grandes vasijas recuperadas junto a los restos humanos. 

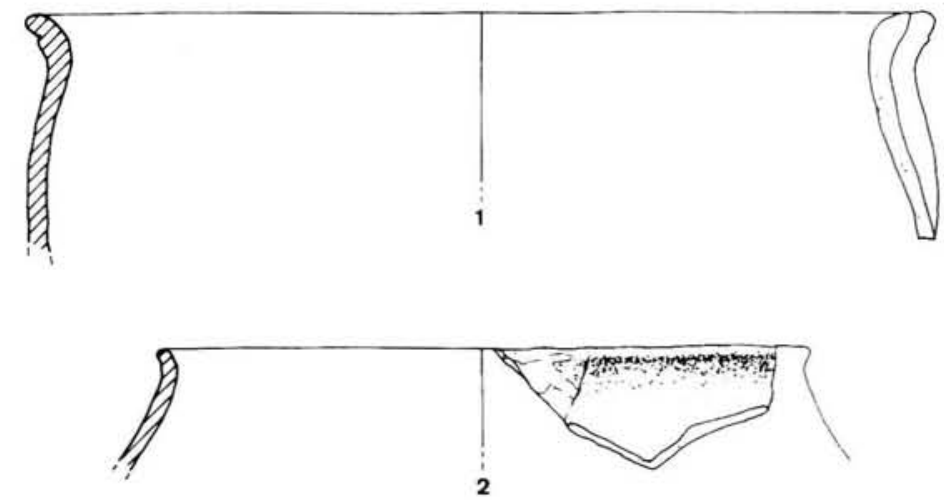
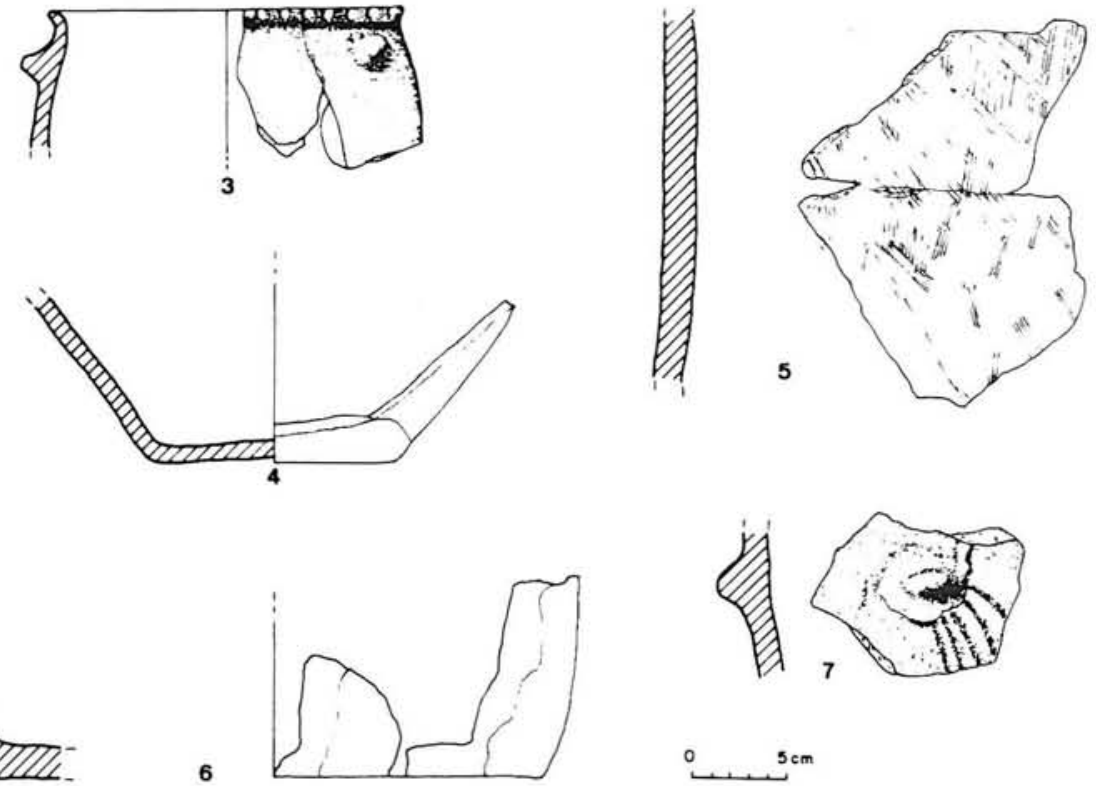

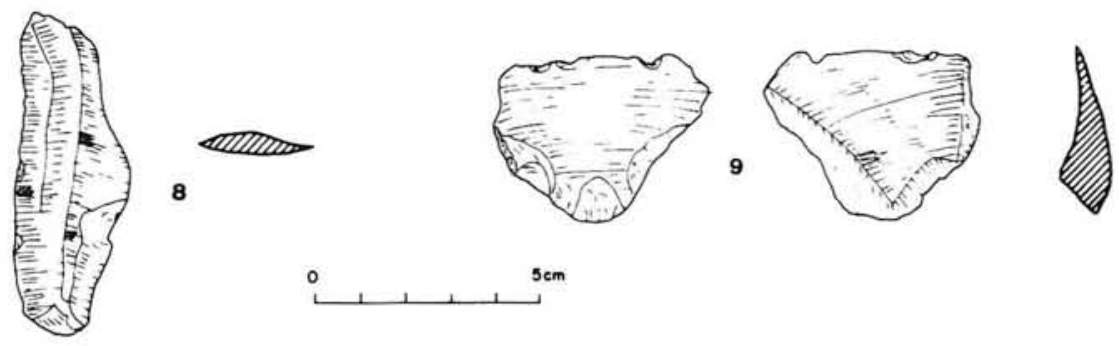

Figura 10.- 1 a 7 Fragmentos de las grandes vasijas recuperadas entre los restos humanos del enterramiento del fondo 20 de la cuadrícula 34/35.- 8 y 9 Lámina y lasca de sílex ${ }^{\wedge} \mathrm{R}$. 
II.- ESTUDIO ANTROPOLOGICO

Francisco J. Robles; V.M. González

A. Gonzallez

UNIDAD DE. ANROROLXXIA

DEP. DE BIOLOXGIA UAM

\section{Resumen}

La excavación arqueológica realizada en la localidad Madrileña de Perales del Río, cercana a Getafe, sacó a luz los restos óseos de varios individuos.

La zona en la que se encuentza este yacimiento pertenece a las terrazas producidas por el curso del ró Manzanares.

\section{Summary}

We present here the Anthropological studie of the human skeletal remains from Bronze Age, which have been discovered in Perales del Río, Madrid.

Los restos arqueológicos encontrados situan el yacimiento en el contexto de la Edad del Bronce.

Los restos óseos están bien identificados para cada individuo aunque el estado de conservación es bastante malo. Esto es debido principalmente a la acción del substrato donde se han encontrado. Las arenas de río con un Ph ácido han ido actuando sobre los restos óseos que se encontraban en contacto con este nivel, de manera que muchos de ellos han desaparecido y otros estan bastante deteriorados.

Se describen a continuación, los restos encontrados, siguiendo el orden de excavación.

\section{INDIVIDUO PR-01.}

Desenterrado en el fondo arqueológico n 30. Fig 2,1. Lámina I b.

Este individuo se encontraba en posición de decúbito lateral derecho con torsión del tronco y con la cabeza apoyada sobre el hombro derecho. 
El terreno sobre el que se hallaba depositado queda en el límite de dos estratos muy diferentes en su composición lo que ha producido un deterioro muy grande en todos los restos óseos que se encontraban situados en el estrato inferior (con Ph muy ácido), preservándose en mejor estado de conservación todas las partes esqueléticas que se encontraban en el estrato superior (con Ph poco ácido).

\section{Neurocráneo}

El cráneo del individuo siglado como PR-01 se encuentra en muy mal estado, conservándose solo la parte izquierda del frontal. El parietal y temporal izquierdo se encuentran también muy deteriorados por lo que no ha sido posible su reconstrucción ni tomar medidas.

\section{Esplacnocráneo}

Del esplacnocráneo solo se conserva la parte superior de la órbita izquierda, parte del malar del mismo lado y un fragmento del maxilar izquierdo, que aún mantiene el canino, ambos premolares y los dos primeros molares en sus alvéolos.

Los dientes se encuentran muy deteriorados. Presentan, en especial, rotura de la raíz. Las piezas mejor conservadas son las superiores.

\section{Dientes Maxilates}

Se han recogido todas las piezas superiores de este individuo.

Sin embargo, algunas de ellas se encuentran muy mal conservadas; de ottas, solo se ha obtenido la corona.

Los incisivos izquierdos aparecen con la raíz y corona completa. El primer incisivo derecho presenta únicamente la corona y el segundo aparece muy fragmentado.

Estas piezas presentan un ligero desgaste. No se ha observado cíngulo o forma de pala.

Los caninos aparecen completos, salvo el derecho, que presenta la raíz ligeramente fragmentada. La corona del canino izquierdo muestra una ligera rocura premorten.

Los premolares del lado derecho se encuentran muy deteriorados. Del Pm1 se conserva la corona y del $\mathrm{Pm} 2$ un fragmento. Los premolares izquierdos se encuentran aún incluidos en los alvéolos maxilares.

El Pm1 derecho presenta la corona ligeramente erosionada.

El premolar 2 izquierdo presenta un alto desgaste del protocono.

El molar 1 derecho solo presenta la corona, mientras el izquierdo se encuentra completo. Ambos muestran un gran desgaste del protocono. El molar 2 derecho presenta la raíz fragmentada, mientras el izquierdo esta completo. Ambos presentan muy ligero desgaste.

El molar 3 derecho solo presenta la corona y el izquierdo se encuentra muy fragmentado. No presentan apenas desgaste.

\section{Dientes Mandibulares}

Unicamente se ha recogido la corona del I1 derecho y restos de un I2. El II presenta un ligero desgaste y una pequeña rotura premorten en la parte superior de la corona . 
El canino izquierdo es el único presente. Este diente aparece completo.

El primer premolar izquierdo es el único recogido. Presenta la raíz fraccionada y un ligero desgaste.

El molar 1 izquierdo presenta el patrón driopitecino típico con 5 cúspides. Muestra un suave desgaste. No se ha encontrado el molar 1 derecho.

Se han obtenido restos de la corona del M2 derecho. Aparece una pieza que probablemente corresponda al molar 2 izquierdo, pero que presenta 5 cúspides, hecho que ocurre aunque no frecuentemente.

No se ha encontrado el molar 3 derecho. El izquierdo presenta un ligerísimo desgaste, apenas perceptible.

(Las medidas de las piezas dentales se recogen en el apéndice final).

\section{Esqueleto postcraneal}

En el esqueleto postcraneal nos encontramos con el mismo problema en cuanto al estado de los restos óseos.

Tan solo ha aparecido un arco vertebral y algunos restos de costillas en los que no se aprecia ningún carácter importante.

Tanto la cintura escapular como la pelviana están completamente deterioradas y muchas de las piezas que lo componian han sido destruidas por el componente ácido del estrato en el que se encontraban incluidas.

En los huesos largos aunque algo menos afectados, también se produce esra situación de deterioro sobre todo en las partes más esponjosas del hueso, las epífisis. Además debido a la posición tan lateralizada del individuo los huesos de la parte derecha tienen sus diáfisis incompletas, incluso en algunos, los fragmentos reconstruidos no alcanzan ni la cuarta parte de tamaño de la diáfisis, como ocurre en el húmero, cúbito y radio. De los huesos de la extremidad inferior el fémur, la tibia y el peroné aparecen más fragmentos pero su estado tan deteriorado en algunas zonas no permiten una mejor recontrucción. La parte izquierda del individuo más preservada del componente ácido del substrato nos ofrece la posibilidad de recostruir en su mayor parte las piezas óseas, que nos ha permitido conocer alguna de las características antropométricas de este individuo.

El húmero mantiene la totalidad de su diáfisis no siendo así en el cúbito y el radio que por su posición de enterramiento se incluían en el substrato más ácido por lo que quedaron bastante destruidos.

El fémur mantiene su diáfisis completa hasta el trocánter menor y por la parte distal hasta la base del triángulo poplíteo.

La tibia aunque deteriorada en una porción de su diáfisis aparece completa desde la meseta tibial hasta la terminación de la diáfisis en su parte distal.

El peroné por su constitución más delicada aparece fragmentado y parte de su diáfisıs distal ha desaparecido.

Se detallan las medidas obtenidas para los huesos largos que han sido reconstruidos en el apendice final.

\section{Carpos, Metacarpos y Falanges.}

Como muchas otras partes del esqueleto, estos restos también se han visto afectados por el componente ácido del substrato. La mano derecha estaba situada por debajo del cráneo del individuo y la izquierda se introducía entre las dos tibias. Se ha obtenido muy poco material por lo que no se puede tomar ninguna medida. 


\section{Tarsos, Metatarsos y Falanges.}

Estos restos merecen gran atención, pues se encontraban casi todos en el estrato superior por lo que se encuentran en buen estado de conservación, sobre todo los metatarsos del pie derecho de los que se ha recogido bastantes medidas que esperamos poder comparar con otras de poblaciones contemporáneas para poder asignar a este individuo a un grupo humano determinado.

De los tarsos encontramos el calcáneo y el astrágalo derechos, éste último ha perdido parte de su materia ósea en la zona de contacto con la tibia donde se podría haber observado la presencia de carillas, fenómeno que se produce muy frecuentemente en las poblaciones antiguas y que viene determinado por la posición que se adopta. Esta posición es en cuclillas y es típica de los individuos que trabajan sin mobiliario.

\section{Patologías}

En el cráneo debido a la escasez de restos no ha podido constatarse la presencia de patologías. En la órbita izquierda no hay restos de criba orbitaria que nos indujera a pensar en algún tipo de anemia.

Los dientes de la maxila I2 izquierdo y M2 derecho presentan una ligera hipoplasia. Ambos caninos y M3 manifiestan una fuerte hipoplasia.

El Il derecho, el M1 izquierdo mandibulares presentan una ligera hipoplasia, siendo más acentuada en el canino izquierdo.

Todos los dientes maxilares, salvo en los Pm2 presentan ligeros restos de cálculo. Los incisivos, el canino y el premolar 1 mandibulares también presentan restos de cálculo.

En ninguna pieza se ha determinado la presencia de caries.

En el esqueleto postcraneal hemos encontrado en el peroné izquierdo una patologia ósea, posiblemente una exóstosis cartilaginosa, que no hubiera determinado en ningún momento la causa de su muerte .

\section{Conclusión final}

La edad de este individuo, teniendo en cuenta la erupción de todas las piezas dentales y el desgaste que presenta (Miles, 1962), oscila entre 20 y 25 años.

Por la constitución y robustez ósea se le considera varón.

A partir de las fórmulas de Manouvier y Pearson se le ha estimado una estatura de $157 \mathrm{~cm}$.

En cuanto a las patologías observadas si tomamos la hipoplasia como un indicador de estrés ambiental, la presencia de ésta en varias piezas dentales pone de manifiesto las condiciones ambientales adversas a que ha estado sometido este individuo durante la infancia.

La platimería del fémur, nos indicaría una posible deficiencia en la alimentación, algo que ocurre muy frecuentemente en las poblaciones más primitivas (Kennedy, 1989).

\section{INDIVIDUO PR-02.}

Desenterrado en el fondo no 20. Fig. 8. Lámina III a, b y c.

Aparece enterrado en posición de decúbito lateral, apoyado sobre el lado derecho pero los restos no se hallan en conexión anatómica total. Presenta un estado de conservación bastante malo en la mayoría de los restos. 
El individuo no se encontraba completo (atlas y axis estaban separados a unos centímetros del resto de este individuo).

\section{Neurocráneo}

El neurocráneo se encuentra deformado. La presión ejercida por el terreno y la colocación lateralizada del individuo han dado como resultado una elongación del cráneo, lo que no nos permite tomar medidas significativas en él. Endocranealmente el hueso esta muy alterado.

La forma del cráneo en norma superior seria probablemente ovalada. El frontal presenta una glabela prominente y canal supraorbitario. Los parietales son grandes y se encuentran unidos por la sutura sagital. Del occipital, solo se conserva la zona de unión a los parietales, estando muy fragmentado el resto del hueso. Los temporales se enctientran igualmente bastante deteriorados conservando parte de la unión con el occipital y la zona auricular. La apófisis mastoides ha desaparecido.

\section{Esplacnocríneo}

En el esplacnocráneo, solo se conserva parte de la órbita izquierda unida con el malar. También se encuentra, aunque bastante fragmentado el maxilar, en el que podemos observar las raices de algunas piezas dentarias que se rompieron postmorten.

En la hemimaxila derecha se conservan 3 Molares y los dos premolares. También se han encontrado los dos incisivos (I2), el Incisivo (I1), y el molar (M2) derecho.

Los 2 incisivos (I2) presentan cíngulo y se observa cálculo dentario en ellos.

Los datos méricos se recogen en el apéndice final.

No se recogió mandíbula en conjunto con el individuo.

\section{Esqueleto postcraneal}

Se encuentra bastante fragmentado y deteriorado, por lo cual es imposible en muchos casos tomar medidas significativas.

Con las piezas que se recuperaron se ha realizado un examen morfológico del que hemos obtenido estos resultados.

\section{Columna Vertebral}

La mayoria de las vértebras han perdido parte del cuerpo, las apófisis espinosas y en algunos casos también las transversas.

Hemos observado, que en los cuerpos vertebrales que se conservan se mantienen visibles las líneas epifisiarias (líneas de crecimiento óseo), por lo que podemos estimar la edad de este individuo como adulto joven .

Las dos primeras vértebras cervicales, Atlas y Axis, presentan mejor estado de conservación, aunque se encontraron separadas del individuo. Corresponden a un individuo adulto y seguramente a este PR-02.

Las costillas se encuentran también muy fragmentadas pero en los restos mejor conservados no se han observado patologías. 


\section{Cintura Escapular.}

Solo se han recogido fragmentos de la parte superior de la escápula.

\section{Cintura Pelviana.}

Solo se conserva el ileon derecho por su parte ventral y el borde del acetábulo.

Las características observadas en la escotadura ciática, el tamaño relativo de la altura del ileon con respecto a su anchura y la dimensión del acetábulo indican que este individuo es de sexo masculino. Esto concuerda con los caracteres observados en el cráneo de este individuo.

\section{Extremidades Superiores}

Aparecen bastante fragmentadas y deterioradas . Se conservan solo parte de la diáfisis y en el caso del Húmero éste solo presenta la mitad longitudinal. Su aspecto es robusto.

El Radio está incompleto y solo hemos podido teconstruir la mitad de su diáfisis.

El Cúbito derecho, presenta solo la diáfisis, desde la zona de inserción del músculo tricipital hasta la mitad distal de la diáfisis.

Se han encontrado fragmentos de huesos que pertenecen al Húmero Cúbito y Radio no descritos. Su reconstrucción no ha sido posible.

De ninguno de estos huesos se pudieron tomar medidas

significativas.

\section{Extremidades Inferiores}

Se encuentran también bastante deterioradas aunque en este caso los fragmentos de diáfisis están completos longitudinalmente.

Se recogieron fragmentos de los dos fémures.

El fémur izquierdo esta incompleto, faltando toda la epífisis superior desde el trocante menor, y desde la mitad de la diáfisis hasta el final de la epífisis distal.

El grosor óseo de la diáfisis es de $7 \mathrm{~mm}$. Las zonas de inserción muscular están marcadas y la línea áspera aparece elevada.

Se midieron los diámetros subtrocantianos, con el fin de calcular el índice de platimería del fémur.

D. sagital $26 \mathrm{~mm}$.

D. transversal $35 \mathrm{~mm}$.

I. Platimérico 74.2 Hiperplatimérico.

El fémur derecho, solo conserva parte de la diáfisis, desde el comienzo del triángulo poplíteo hasta la zona de inicio de la epífisis distal. El perimetro medido a nivel del vértice superior del triángulo es de $74 \mathrm{~mm}$, y el grosor óseo en esta misma zona es de $7 \mathrm{~mm}$.

Tibia Izquierda: incompleta, presenta solamente un fragmento de la diáfisis de $170 \mathrm{~mm}$, que comprende desde la tuberosidad tibial, que solo presenta la parte anterior hasta el foramen nutricio, hasta las proximidades del final de la espina tibial.

Los diámetros medidos a nivel del foramen nutricio son los siguientes.
D. sagital $28 \mathrm{~mm}$.
D. transversal. $22 \mathrm{~mm}$.
I. platinécmico 78.5 Eurynécmico. 
De la Tibia derecha solo se han recogido pequeños fragmentos, de manera que no ha sido posible su reconstrucción.

De los restos de Peroné solo ha sido posible reconstruir parte de la diáfisis que no presenta características especiales.

No se han observado patologías en ninguno de los huesos latgos examinados.

Los demás restos óseos: Carpos, Metacarpos, Tarsos, Metatarsos y Falanges presentan también un estado de conservación bastante malo, sobre todo en el Calcáneo y Astrágalo que por su constitución, con un gran cuerpo de hueso esponjoso son muy frágiles .

En los restos de metacarpos, metatarsos y falanges, examinados no se han observado patologías.

\section{Conclusión final}

Se trata de un individuo adulto joven, con una edad comprendida entre los 20 - 25 años de sexo varón.

\section{RESTO PR-03.}

Se trata de una mandibula aislada, encontrada en el fondo $n^{\circ} 35$.

Aunque estaba muy fragmentada el estado del hueso era bastante bueno por lo que se ha podido llevar acabo su reconstrucción.

La hemimandibula izquierda esta casi completa faltando únicamente el cóndilo. La hemimandíbula derecha presenta numerosas roturas postmorten, no permitiendo recomponer parte de la rama ascendente, el goniom y el cóndilo.

En lo referente a la dentición, no se conserva ni se ha podido reconstruir ninguna pieza completa, excepto el primer premolar izquierdo ( $\mathrm{Pm} 1$ ). Todos las piezas presentan rotuta a nivel de la corona. Se ha observado que ninguna pieza se ha perdido premorten ya que la mandíbula presenta perfectamente definidos los alvéolos en los que se implanta la raiz dentaria.

La hemimandibula derecha presenta alvéolo para la inserción del tercer molar, mientras que en la hemimandíbula izquierda el alvéolo no existe. Este tercer molar no se encontró en el interior de la mandíbula.

Teniendo en cuenta el desgaste en la superficie coronaria de las piezas que se han podido reconstruir, podemos concluir que se trata de un individuo joven, de edad comprendida entre los 18 y 24 años.

El sexo de la mandíbula, teniendo en cuenta los criterios de la W.E.A, corresponde a un individuo varón.

Las medidas de la Mandíbula se recogen en el apéndice final.

\section{INDIVIDUO PR-04.}

Encontrado en el fondo $n^{\circ} 21$. Fig. 3. Lámina II a.

También se encontraba en posición de decúbito lateral. El cráneo aparecía apoyado sobre un cuenco de cerámica.

Su estado de conservación es en general bastante deficiente y esta muy fragmentado, habiéndose perdido la mayoria de las zonas de tejido esponjoso de los huesos. 


\section{Cráneo}

El cráneo ha permitido una reconstrucción parcial de los distintos huesos aunque se han perdido o están muy deterioradas las zonas de unión entre ellos.

En el frontal se ha reconstruido toda la parte anterior y la casi toda la mitad derecha que se extiende por la sutura coronal a parte del parietal derecho. La glabela no es muy prominente y la frente se inclina hacia atrás.

En el temporal se puede apreciar la apófisis mastoides que tiene un tamaño medio.

El grosor del hueso craneal en los parietales es de $6 \mathrm{~mm}$.

\section{Esplacnocráneo}

Tan solo se conservan fragmentos del maxilar y el malar izquierdo. Existen además multitud de pequeñísimas piezas que formarían parte del esfenoides y del etmoides .

En el maxilar podemos apreciar dentro de los alvéolos las raíces de las piezas dentarias. Todas las roturas han sido postmortem.

De este individuo se han recogido todas las piezas dentales tanto maxilares como mandibulares, a excepción de los dos caninos superiores.

El estado de conservación no es muy bueno, especialmente en los premolares y molares superiores que están fracturados a nivel de unión de la corona con las raíces. El tercer molar inferior izquierdo se encuentra fracturado tanto a nivel de corona como de raíces.

De la mandíbula, aparecen numerosos restos muy fragmentados siendo imposible su reconstrucción. Solamente la persistencia de algunas piezas dentarias en los alvéolos, como los incisivos y el canino derecho permiten determinar la posición de los restos mandibulares.

Las coronas de todos los dientes aparecen muy erosionadas, e incluso hay piezas que presentan ligeras fracturas premorten, tal es el caso del segundo molar mandibular derecho y los cuatro premolares mandibulares. El grado de desgaste varia de unas piezas a otras siendo muy acentuada en los primeros molares y en los incisivos.

Por el estado de la dentición, hemos estimado que este individuo es adulto, con una edad comprendida entre 30-50 años.

La dentición maxilar es la peor conservada. Todas las piezas dentales se encuentran fuera de sus alvéolos. Los premolares presentan fracturas premorten. La corona de ambos incisivos 1 aparece bastante erosionada.

La dentición mandibular esta completa. Teniendo en cuenta las medidas de la corona , parecen dientes bastante pequeños, aunque debemos tener en cuenta el gran desgaste que presentan.

\section{Patologías}

Se manifiesta Hipoplasia en numerosos dientes .Así, todas las piezas Mandibulares, con excepción de los premolares, presentan una hipoplasia mas o menos marcada. Los molares y segundos incisivos superiotes también presentan una ligera hipoplasia.

Además este individuo, presenta varias caries.

El segundo premolat tanto maxilar como mandibular del lado derecho manifiestan una caries en el cuello, en posición distal. También se observa una caries en el cuello, en posición mesial, del 
primer molar mandibular derecho, así como en el cuello, en posición distal, del segundo molar mandibular derecho.

Algunos dientes presentan ligeros restos de sarro, aunque esta capa que se forma alrededor de la corona es dificil de conservar, puede observarse en el I2 izq. , M2 y M3 derechos e izquierdos y en el fragmento del M3 izquierdo.

\section{Esqueleto postcraneal}

Se encuentra en general bastante deteriorado.

\section{Cintura Escapular.}

La escapula izquierda esta incompleta, solo conserva parte de la cavidad glenoidea y el acromiun esta también incompleto.

La apbfisis coracoides ha desaparecido.

Su tamaño ha juzgar por los restos no es muy grande.

La escápula derecha está totalmente fragmentada.

La clavícula izquierda esta incompleta, falta el extremo proximal y parte del distal.

Perímetro $32 \mathrm{~mm}$.

\section{Columna Vertebral.}

Solo se conservan pequeños fragmentos que no es posible restaurar. No se ha encontrado ningún resto de cuerpo vertebral.

Las costillas también están bastante fragmentadas pero no hay restos de patologías.

\section{Cintura Pelviana.}

Solo se han encontrado pequeños fragmentos del cuerpo iliaco y parte de la sínfisis púbica que esta erosionada. Esta es pequeña y estrecha. Las marcas son pequeñas y los bordes están bien delimitados en los laterales. Posiblemente en estado VII - VII

(Olivier 1978).

\section{Huesos Largos}

En general se encuentran bastante fragmentados y deteriorados habiendo desaparecido casi todas las zonas epifisiarias.

Tan solo se han podido reconstruir las diáfisis de algunos de los huesos. Las medidas tomadas de longitud máxima se han determinado siguiendo el método empleado por Stell (70), para huesos fragmentados.

\section{Extremidades Superiores}

Húmero izquierdo incompleto, solo presenta la diáfisis desde su extremo proximal hasta el borde superior del olécranon.

El aspecto general es grácil y las zonas de inserción muscular están ligeramente marcadas.

Cúbito izquierdo incompleto, solo se conservan la diáfisis desde la ruberosidad radial. La Epífisis distal también ha desaparecido.

Radio izquierdo incompleto, solo se ha podido reconstruir la diáfisis desde el comienzo del borde interóseo hasta el comienzo de la epifisis distal. 


\section{Extremidades Inferiores}

Fémur derecho incompleto, solo se conserva la diáfisis desde el cuello femoral que está parcialmente destruido hasta la base del triángulo poplíteo.

Las zonas de inserción muscular están ligeramente marcadas y la línea áspera no está muy elevada.

El fémur Izquierdo está muy fragmentado y deteriorado, solo conserva parte de la zona media de la diáfisis.

Tibia izquierda: incompleta ,solo se conserva la diáfisis desde la tuberosidad tibial, zona que aparece destruida por parte posterior hasta el foramen nutricio ,hasta el comienzo de la epífisis distal.

Tibia derecha muy fragmentada, solo se conserva la parte central de la diáfisis.

De ambos peronés solo se han tecogido pequeños fragmentos de las diáfisis.

\section{Carpos, Metacarpos y Falanges.}

Los carpos aparecen completos, faltando solo algún pequeño fragmento.

$E_{n}$ los metacarpos y falanges la fragmentación es mayor y solo algunas piezas aparecen completas.

En los restos que se han examinado no se han encontrado patologías ni caracteres especiales. Tan solo apuntar que el tamaño es pequeño.

\section{Tarsos, Metatarsos y Falanges.}

El Calcáneo y el Astrágalo se encuentran bastante deteriorados, habiendo perdido parte del cuerpo. Los otros tarsos se encuentran casi completos, faltándoles tan solo algún pequeño fragmento.

Los metatarsos y falanges, al igual que en las manos tan solo algunos aparecen completos. Tampoco se han observado patologias en ellos.

\section{Conclusión final}

Se trata de un individuo adulto con una edad comprendida entre 30 y 50 años de sexo probablemente femenino, su estatura estaria entre $1.52-1.58 \mathrm{~m}$.

Teniendo en cuenta que la Hipoplasia dentaria es un marcador de estrés ambiental, podemos concluir que este individuo durante la infancia (etapa de formación de la dentición) estuvo sometido a condiciones ambientales adversas, desnutrición alguna enfermedad infecciosa, etc.

\section{INDIVIDUO PR-05.}

Encontrado en el fondo $n^{\circ} 23$.

Estaba enterrado junto con el individuo PR-06. Fig 5,1. Lámina I c.

El estado de conservación es bastante malo, por lo que no se han podido reconstruir la mayoría de los restos.

\section{Neurocráneo}

Incompleto.Aparece muy deformado por causa del terreno. Falta la mayor parte del occipital, la zona superior del frontal y el parietal izquierdo. Las sururas aparecen sin terminar de fusionar tanto endocraneal como ectocranealmente.

El la zona superior del interior orbitario se puede apreciar una ligera criba orbitaria. 


\section{Esplacnocráneo}

Incompleto. Solo se conserva la hemimaxila izquierda unida a parte del malar del mismo lado.Se conservan algunas piezas dentales, incluidas en los alvéolos: canino y molares l y 2 deciduales y molar 1 permanente. El canino, los premolares y el molar 2, permanentes se encuentran en formación dentro de la mandfbula.

Otras piezas aparecen sueltas, como el molar 1 decidual derecho, en el que se observa por su parte inferior el premolar 1 permanente formándose.Aparecen también sueltas el 2 molar decidual derecho y molar 1 permanente derecho, incisivos permanentes y canino decidual.

\section{Mandibula}

Incompleta Se conserva la hemimandibula izquierda sin la rama y parte del mentón con los incisivos derechos. En los alvéolos dentarios aparecen los cuatro incisivos permanentes, los dos molares deciduales y los dos primeros molares permanentes.

El segundo molar aparece todavía sin terminar de erupcionar.

Las piezas de la hemimandíbula derecha se encuentran sueltas debido a que esta parte esta muy fragmentada e incompleta.

\section{Patologías dentarias}

Se ha observado ligeta hipoplasia continuada en numerosos dientes, que habría empezado a producirse a una edad entre 3 y 4 años.

\section{Esqueleto postcraneal}

En general se encuentra bastante deteriorado.

\section{Extremidades Superiores}

Húmero derecho:incompleto. Solo se conserva la mitad proximal de la diáfisis.

Radio izquierdo:incompleto. Solo se conserva la mitad distal de la diáfisis. La epífisis distal aparece sin fusionar.

Cúbito Izquierdo:incompleto. Solo se conserva parte de la diáfisis.

Los otros huesos no han podido ser reconstruidos.

No se han apreciado en los restos examinados ninguna patología.

\section{Extremidades Inferiores}

Fémur derecho e izquierdo:incompletos. Solo conservan la diáfisis y parte de la zona de unión con la epifisis distal. Tibia Izquierda:incompleta.solo conserva la mitad superior de la diáfisis hasta la meseta tibial.

Se han encontrado también fragmentos de costillas y algunas falanges.

Tampoco se han encontrado patologías en estos restos. 


\section{Conclusión final}

Se trata de un individuo infantil.La edad estimada de acuerdo con la dentición es de nueve años. La patología observada en la órbita nos indicaría que este individuo padeció algún tipo de anemia o malnutrición.

\section{INDIVIDUO PR-06.}

Encontrado junto con el individuo anterior en el mismo fondo.

Aparece también en mal estado de conservación.

\section{Neurocráneo}

Incompleto. Solo se conservan algunos fragmentos de los parietales y temporales (faltan las escamas temporales), y parte del occipital. Las suturas están sin fusionar.

\section{Esplacnocráneo}

Aparece muy deteriorado e incompleto, solo aparece parte del maxilar.

De las piezas maxilares, se han recuperado los incisivos un canino y los molares 1 y 2 , todos ellos deciduales, y los incisivos 1 y 2 los molares 1 y 2 permanentes.

\section{Mandibula}

Incompleta y fragmentada en dos piezas, la dentición no se conserva cotalmente, aparecen todavía en los alvéolos :el canino y molares 1 y 2 izquierdos deciduales y el molar 2 derecho decidual.

Incluidos en el interior mandibular podemos observar el incisivo 2 izquierdo y los molares 1 y 2 permanentes que aún no han erupcionado.

El incisivo 1 izquierdo, premolar 1 derecho, molar 1 y 2 izquierdos, permanentes, aparecen sueltos.

En ninguna de las piezas examinadas se han observado restos de hipoplasia. Los incisivos 1 superiores, aparecen muy desgastados y erosionados, probablemente causado por la arena que se mezcla con los cereales al fabricar la harina, o por consumir alguna raíz sin limpiar.

\section{Esqueleto postcraneal}

Muy deteriorado y fragmentado solo se conserva parte de la diáfisis del húmero izquierdo y parte del cúbito derecho.De los otros huesos, no aparecen mas que pequeños fragmentos, que no permiten su reconstrucción.

\section{Conclusión final}

Se trata de un individuo infantil. La edad estimada de acuerdo con la dentición es de 4 o 5 años.

No presenta en los huesos analizados ningún tipo de patología. 


\section{INDIVIDUO PR-07.}

Desenterrado en el fondo $\mathbf{n}^{\circ} 11$. Fig 7 . Lámina II c y II d.

De los restos encontrados en este yacimiento, este es el que aparece en mejor estado de conservación. La situación del individuo por encima de el suelo de arenas de rio, y su posición de enterramiento han permitido su buena preservación y que solo alguno de los huesos contactara con esta capa de terreno.

Todos los huesos se hallan recubiertos de una concreción calcárea muy unida al periostio óseo.

Aparece este individuo, apoyado sobre la espalda con las piernas flexionadas y dirigidas lateralmente. Las manos montadas una sobre otra, reposan en la parte derecha del rostro.

\section{Neurocráneo}

El cráneo, aparece con todos los huesos completos a excepción del occipital que al permanecer en contacto con el substrato ácido ha desaparecido. Se observa en la zona de contacto de este hueso con los parietales y temporales el efecto de la erosión producido por el substrato. Debido a la falta de este hueso los parietales se han deformado, lo que ha originado un abombamiento del cráneo.

Falta también casi todo el esfenoides y el parte del etmoides.

El frontal, presenta una glabela poco prominente y la frente alta.

En los temporales podemos observar que la apófisis mastoides es de tamaño medio.

No se han tomado las medidas de longitud, anchura y altura máximas, debido a que los puntos craneométricos habían desaparecido con el occipital y los parietales estaban deformados.

\section{Esplacnocráneo}

Se conserva en muy buen estado y no ha suffido ninguna deformación.

La cara de este individuo es alra y se puede apreciar cierto prognatismo en la maxila.

Se han tomado las medidas más importantes (ver apendice final).

\section{Maxila y mandibula}

La hemimaxila derecha aparece completa, con todas las piezas dentales incluidas en sus alvéolos (a excepción de los molares que el individuo ha perdido durante el transcurso de su vida).

La hemimaxila izquierda se encuentra fragmentada tras el segundo premolar, apareciendo el molar I libre y el molar 2 incluido en su alvéolo, pero aislado del resto de la maxila. Las demás piezas dentarias aparecen incluidas en sus alvéolos, a excepción del M3 que seguramente se perdió premortem.

Al igual que en la mandíbula, en ambos maxilares aparece una fina capa de concreciones.

Las coronas de todos los dientes aparecen bastante erosionadas, en especial, los incisivos mandibulares y los dientes maxilares.

Su superficie de masticación ha perdido en todos ellos el esmaite, mostrando la denrina. En ningún molar puede apreciarse el relieve de surcos y cúspides de la corona.

El segundo premolar derecho mandibular se halla muy desgastado en su parte vestibular, como consecuencia del roce, en la masticación, con el Pm2 maxilar y probablemente con el primer molar.

Podemos observar ligeras roturas en el esmalte del canino, en ambos premolares derechos maxilares y en el segundo premolar izquierdo de la maxila. La rotura que muestra el premolar 2 dere- 
cho puede estar relacionada con la presencia de una caries a nivel cervical en posición distal, y que con toda probabilidad, ha incidido en la corona, debilitándola, y facilitando la fragmentación de ésta.

El estado de la dentición nos permite estimar que el individuo posee una edad superior a los 30 años y probablemente inferior a los 42 .

Teniendo en cuenta la morfología de la mandíbula, (por su aspecto, forma redondeada del mentón, ángulo goniáco y borde inferior), este individuo es del sexo femenino.

Los diámetros mesio-distales y vestibulo linguales de la corona de estas piezas dentales, así como los caracteres métricos de la mandíbula, aparecen reflejados en el apéndice final.

\section{Patologías}

La dentición presenta varias caries. El segundo molar mandibular izquierdo presenta una caries a nivel cervical, en la cara proximal. El premolar 2 inferior manifiesta un indicio de caries en el cuello, en posición distal.

En la maxila, el premolar 2 derecho muestra una caries que se inició en el cuello, en posición distal, y que ha incidido profundamente en la corona. El primer premolar izquierdo presenta una caries que se inició en el cuello, en la cara proximal, y que se ha extendido a la corona.

El segundo premolar maxilar origina un abceso, como consecuencia del mal estado de esta pieza dentaria.

Todos los dientes, tanto maxilares como mandibulares, presentan restos de cálculo, que se ha consolidado con la concreción.

No se puede observar, por las abundantes concreciones en torno al cuello y base de la corona, la presencia de hipoplasia. Sin embargo, los dientes que han perdido esas concreciones no manifiestan hipoplasia.

Eliminando estas concreciones en los caninos mandibulares y maxilares, piezas dentales que con más frecuencia manifiestan la hipoplasia, no se han observado restos patentes de ésta.

\section{Esqueleto postcraneal}

El estado de conservación es bastante bueno en todos los restos, excepto en la vértebras, sacro $y$ algunas falanges de los pies, donde la acción del terreno las ha erosionado .

\section{Columna Vertebral.}

Las vértebras se hallan unidas unas a otras debido al recubrimiento calcáreo.No se han observado restos de artrosis en ninguna de ellas, ni osteporosis en ninguno de los cuerpos vertebrales examinados.

\section{Cintura Escapular.}

Ambos omóplatos presentan la lamina escapular deteriorada.

En la escápula derecha podemos apreciar, que no se ha producido la fusión del proceso acromial.

Esto podria deberse a fuertes tracciones ejercidas por el musculo deltoides producidas por la continuada carga de objetos pesados, Kennedy (89).

La clavícula derecha se halla deteriorada en sus dos extremos, el perímetro en medio es de $31 \mathrm{~mm}$

La clavícula izquierda se encuentra completa, con las siguientes medidas. 
Longitud máxima ..................................................... $146 \mathrm{~mm}$.

Perimetro mínimo …………………………………... $30 \mathrm{~mm}$.

Anchura extremo proximal ......................................... $24 \mathrm{~mm}$.

Anchura extremo distal .............................................. $23 \mathrm{~mm}$.

Las inserciones musculares en ambas clavículas están ligeramente marcadas. En ninguna de las dos se han observado patologias.

\section{Tórax}

El esternón conserva el manubrio en perfecto estado ,también se conserva la parte proximal del cuerpo. No se observan patologias en ninguno de estos restos.

Costillas. Muchas de ellas aparecen fragmentadas. En ninguna se han observado patologías.

\section{Cintura Pelvica}

Hueso sacro. Solo conserva la primera parte del cuerpo, las apófisis transversales de esta zona se hallan deterioradas, aunque permanece parte de la superficie de articulación con el coxal. El cuerpo vertebral aparece muy erosionado debido a la acción del suelo.

El coxal derecho se encuentra casi completo, faltando parte del isquion y el pubis; el acetábulo se encuentra deteriorado.

En la cara articular del ileon con el sacro, se ha perdido parte de la materia ósea.

Anchura máxima $155 \mathrm{~mm}$.

Se han observado en el surco preauricular ciertas marcas, que se forman en las mujeres que han sufrido algún parto, por lo que podemos suponer que esta mujer ha sido fértil.

El coxal izquierdo mas enterrado en el nivel de arenas, se encuentra bastante deteriorado. Han desaparecido el isquion y el pubis; la zona de el surco preauricular esta también destruida en su mayor parte.

\section{Extremidades} rada.

Todos los huesos largos están muy bien conservados y solo alguna de las epífisis se halla alte-

Todas las medidas que se han recogido se muestran en la.

\section{Extremidades Superiores}

Húmero. No presentan ninguno de ellos características especiales. En el húmero derecho se observa perforación olecraneana, no siendo así en el izquierdo.

Esta perforación se clasifica según Hrdlicka (32) como grande, e indicaría que este individuo presentaría hiperextensión (dorsiflexión) en el brazo derecho.

Ambos húmeros son eurybraquios.

No se han advertido patologias en ninguno de ellos.

Cúbito. En el cúbiro izquierdo se ha observado que la diáfisis es mas corta que en el derecho, aunque ambos son normales y no presentan parologias .

Radio. Ambos radios son normales y no presentan características morfológicas especiales. La diferencia en longitud entre los dos radios está en relación con la observada en los cúbitos.

También se puede apreciar un ligero engrosamiento en la parte proximal del radio izquierdo, desde el final de la epifisis hasta el comienzo de la cresta interósea.

No se observan patologias en ninguno de los dos radios. 
Carpos, Metacarpos y Falanges.

En general presentan un estado de conservación bastante bueno, faltando solo algún pequeño fragmento. No se han observado características especiales ni patologias en ninguna de las dos manos.

\section{Extremidades Inferiores}

Fémur derecho: completo, no presenta características especiales. Las zonas de inserción muscular están marcadas y la línea áspero es elevada, es platimérico y presenta un índice pilástrico medio.

El fémur izquierdo se halla un poco deteriorado en ambas epifisis. Es mas robusto que el derecho, platimérico y con índice pilástrico medio.

En ninguno de los dos fémures se han observado patologias.

Tibia derecha:incompleta. Ambas epifisis aparecen bastante deterioradas.No presenta caracterísricas especiales.

Es platinécmica.

Tibia izquierda: se encuentra bastante bien conservada.Solo parte de la epifisis distal ha desaparecido. Como ocurre con el fémur esta tibia es mas robusta que la derecha.

Es platinécmica.

Presenta en la epifisis inferior carillas tibiales, carácter frecuente en individuos que trabajan en cuclillas.

No se han observado patologias en ninguna de las dos tibias.

\section{Tarsos, Metatarsos y Falanges.}

Han sido alterados por la acción del suelo. El calcáneo esta muy dereriorado, falcando toda su parte posterior.

El astrágalo se encontraba también fragmentado, aunque ha sido posible reconstruirlo parcialmente.

Los metatarsos presentan buen estado de conservación y no hemos observado características especiales ni patologias.

Algunas de las falanges han desaparecido, seguramente debido a la acción del suelo. Las falanges examinadas son normales y no presentan parologias.

\section{Conciusión final}

Se trata de un individuo adulto joven, de sexo femenino con una edad comprendida entre 30 y 42 años. La estatura de esta mujer es 1,56-1,62 m.

Las asimetrías que exisren entre ambos lados del cuerpo son normales.

No se han observado patologías en ninguno de los restos examinados. 


\section{BIBLIOGRAFIA}

KENNEDY, K. A. R., 1989. Skeleral markers of occupational stress. Reconstruction life from the skeleton. Alan R. Liss, Inc, 1989. Págs 129-160.

KROGMAN, W. M.\& ISCAN, M. Y.1986. The human skeleton in forensic medicine. Charles C. Thomas Publisher.

MiLES, A. E. W., 1963. The dentition in the assessment of individual age in skeletal material. En "Dental Anthropology, 191-209". Ed. Brothwell, Pergamon Press.

OlIVIER, G., 1960. Practique Anthropologique. Edr. Mason

ORTNER, D. J. \& PUTSCHAR, W. G. J., 1985. Identification of pathological conditions in human skeleton remains. Edt. Smithsonian institution press.

STEEIE, D. G. \& MCKERN, T. W., 1970. A method for assessment of maximum long bone length and living stature from fragmentary long bones. Am. J. Phys. Anthrop, 31. Págs 215-228. 


\section{APENDICE}

DATOS METRICOS DE LAS PIEZAS DENTALES

Individuo PR-OI. (Todas las medidas en $\mathrm{mm}$.)

\begin{tabular}{|c|c|c|c|c|c|}
\hline & & & & & LAR \\
\hline & & Derecho & Izquierdo & Derecho & Izquierdo \\
\hline I1 & $\mathrm{MD}$ & 8.4 & 8.5 & 5.2 & 5.2 \\
\hline & $\mathrm{VL}$ & 7.4 & 7.5 & 5.8 & 5.8 \\
\hline I2 & $\mathrm{MD}$ & - & 6.1 & - & - \\
\hline & VL & - & 6.2 & - & - \\
\hline C & MD & 7.8 & 7.7 & - & 7.2 \\
\hline & VL & 8.9 & 8.8 & - & 8.2 \\
\hline $\mathrm{Pml}$ & MD & 7.1 & 7 & - & 7 \\
\hline & $\mathrm{VL}$ & 9.5 & 9.4 & - & 7.8 \\
\hline $\mathrm{Pm} 2$ & MD & - & 6.2 & - & - \\
\hline & VL & - & 8.2 & - & - \\
\hline M1 & $M D$ & 10.2 & 10.3 & - & 11.2 \\
\hline & VL & - & 12.1 & - & 10.2 \\
\hline M2 & MD & 8.4 & 8.4 & 10.8 & 11.1 \\
\hline & VL & 11.8 & 11.8 & 9.2 & 9.3 \\
\hline M3 & MD & 8 & 8 & - & 9.3 \\
\hline & $\mathrm{VL}$ & 10.7 & 10.7 & - & 8.6 \\
\hline
\end{tabular}




\section{DATOS METRICOS DE LOS HUESOS LARGOS \\ Individuo PR-OI}

\section{HUMERO IZQUIERDO}

Longitud máxima. $289 \mathrm{~mm}$.

Perimetro mínimo. $68 \mathrm{~mm}$.

Diámetro máximo $24 \mathrm{~mm}$.

Diámetro mínimo $21 \mathrm{~mm}$.

Indice de Robustez

23. 5

Indice Diafisiario.

87.5 Eurybraquio

\section{FEMUR DERECHO}

Longitud $.409 \mathrm{~mm}$.

Perímetro en la mitad $87 \mathrm{~mm}$.

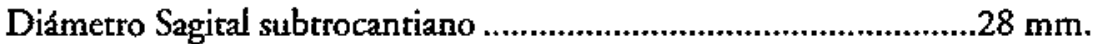

Diámetro Transversal subtrocantiano ..........................................34 mm.

Diámetro Sagiral en el medio ..........................................................29 mm.

Diámetro Transversal en el medio ..................................................26 mm.

Indice de Robustez .........................................................................21.2

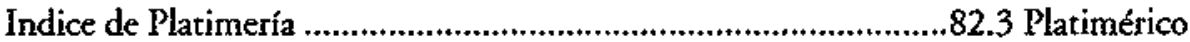

Indice Pilástrico.....................................................................111.53. Medio

\section{TIBIA IZQUIERDA}

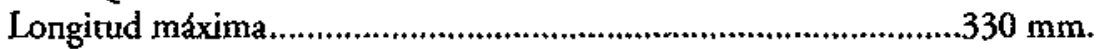

Perímetro mínimo...........................................................................80 mm.

Diámetro Sagiral en el foramen nutricio ..........................................

Diámetro Transversal en el foramen nutricio .................................36 mm.

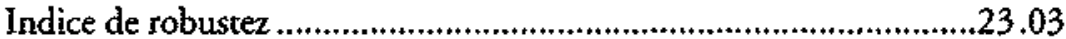

Indice de platinécmia ...............................................................70.58 Eurinécmico

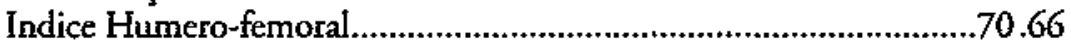

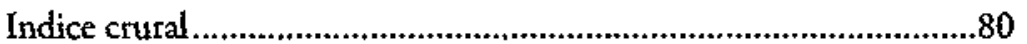

Estatura (Pearson) .................................................................. $1.64 \mathrm{~m}$. 


\section{METATARSOS DERECHOS}

Individuo PR-OI

\begin{tabular}{|l|c|c|c|c|c|}
\hline & MT I & MT II & MT III & MT IV & MT V \\
\hline Longitud Máxima. & - & 80 & 74 & 74 & 71 \\
\hline Longitud Mínima Interarticular. & 65 & 77 & 73 & - & 64 \\
\hline $\begin{array}{l}\text { Anchura Superficie Articular } \\
\text { Epifisis proximal. }\end{array}$ & - & - & 13 & - & 16 \\
\hline $\begin{array}{l}\text { Longitud Superficie Articular } \\
\text { Epifisis proximal. }\end{array}$ & - & - & - & - & 13 \\
\hline Longitud Máxima proximal. & - & - & - & - & 13 \\
\hline Anchura Epífisis distal. & - & - & - & - & 10 \\
\hline Longitud Epifisis distal. & - & - & - & - & 16 \\
\hline $\begin{array}{l}\text { Anchura Diáfisis en punto medio. } \\
\text { Longitud Diáfisis en punto medio. }\end{array}$ & - & 9 & 9 & 9 & 8 \\
\hline
\end{tabular}

\section{DATOS METRICOS DE LA MANDIBULA PR-03. \\ (medidas en $\mathrm{mm}$., excepto indices en \%).}

Longitud max. mandibular. .98

Altura de la rama

Angulo mandibular

Longitud del cuerpo

70 .

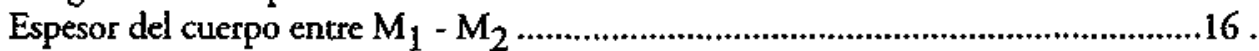

Espesor de la sínfisis

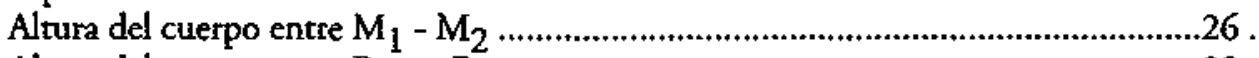

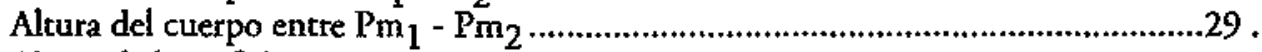

Altura de la sinfisis

Longitud min. de la rama.

Longitud bigoniaca

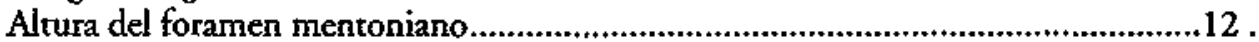

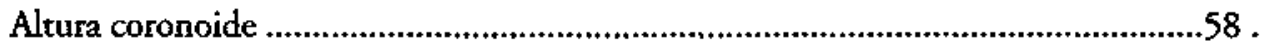

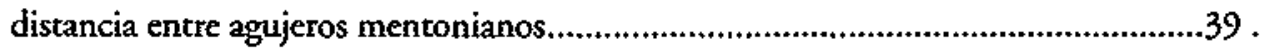

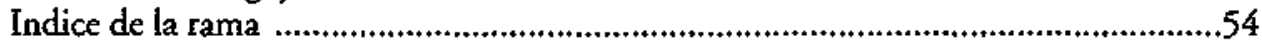

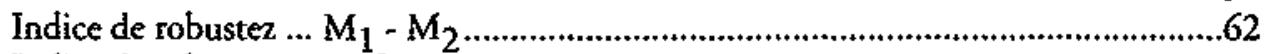

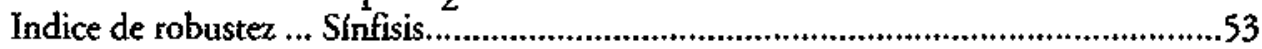

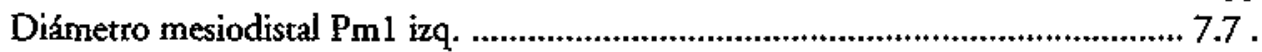

Diámetro vestíbulo-lingual Pm1 izq. ................................................................. 7.5 .

Longitud de la superficie masticatoria..............................................................44 
DATOS METRICOS DE LAS PIEZAS DENTALES (PR-04).

(Todas las medidas en $\mathrm{mm}$.)

\begin{tabular}{|c|c|c|c|c|c|}
\hline & & & & & LAR \\
\hline & & Derecho & Izquierdo & Derecho & Izquierdo \\
\hline Il & MD & 7.5 & 7.5 & 4.7 & 4.7 \\
\hline & VL & 7.3 & 7.4 & 5.3 & 5.3 \\
\hline I2 & $\mathrm{MD}$ & 6.5 & 6.3 & 5.0 & 5.4 \\
\hline & VL & 6.4 & 6.2 & 6.0 & 6.1 \\
\hline C & MD & - & - & 6.3 & 6.4 \\
\hline & VL & - & - & 6.8 & 6.7 \\
\hline Pm & $\mathrm{MD}$ & 6.4 & 6.6 & 6.4 & 6.2 \\
\hline & $\mathrm{VL}$ & 8.4 & 8.6 & 6.8 & 6.9 \\
\hline $\mathrm{Pm} 2$ & MD & 6.3 & 6.6 & 6.7 & 6.7 \\
\hline & VL & 8.0 & 8.3 & 7.6 & 7.5 \\
\hline M1 & MD & 11.4 & 10.8 & 10.5 & 10.5 \\
\hline & VL & 10.0 & 9.9 & 10.2 & 9.8 \\
\hline M2 & MD & 11.1 & 10.8 & 10.2 & 10.2 \\
\hline & VL & 9.2 & 9.2 & 9.5 & 9.6 \\
\hline M3 & MD & 10.7 & 10.6 & 10.1 & - \\
\hline & VL & 8.7 & 9.1 & 9.4 & - \\
\hline
\end{tabular}




\section{DATOS METRICOS DE LOS HUESOS LARGOS \\ Individuo PR-04}

\section{HUMERO IZQUIERDO}

Longitud máxima. $289.1 \mathrm{~mm}$.

Perfmetro mínimo $57 \mathrm{~mm}$.

Diámetro máximo $21 \mathrm{~mm}$.

Diámetro mínimo $20 \mathrm{~mm}$.

Indice de robustez 19.7

Indice Diafisiario 95.2Eurybraquio

\section{FEMUR DERECHO}

Longirud $.412 .5 \mathrm{~mm}$

Perímetro en la mitad. $80 \mathrm{~mm}$.

Diámetro sagital subtrocantiano $23 \mathrm{~mm}$.

Diámetro transversal subtrocantiano $32 \mathrm{~mm}$.

Diámetro sagital en el medio. $26 \mathrm{~mm}$.

Diámetro transversal en el medio ..................................................25 mm.

Indice de robustez 19.3

Indice de platimería 71.8 Hyperplatimerico

Indice Pilástrico 104 .Débil

\section{TIBIA IZQUIERDA}

Longitud máxima.

Perimetro mínimo $344.7 \mathrm{~mm}$.

Diámetro sagital en el foramen nutricio. $.66 \mathrm{~mm}$.

Diámetro transversal en el foramen nutricio $31 \mathrm{~mm}$.

Indice de robustez $20 \mathrm{~mm}$.

Indice de platinécmia 19.1

Indice Humero-femoral 64.5 Mesonécmico

Indice crural. 70.08

Estatura (Pearson) 83.56 $1.52 \mathrm{~m} .-1.58 \mathrm{~m}$. 
MEDIDAS DE LAS PIEZAS DENTALES

Individuo PR-07. (Todas las medidas en $\mathrm{mm}$.)

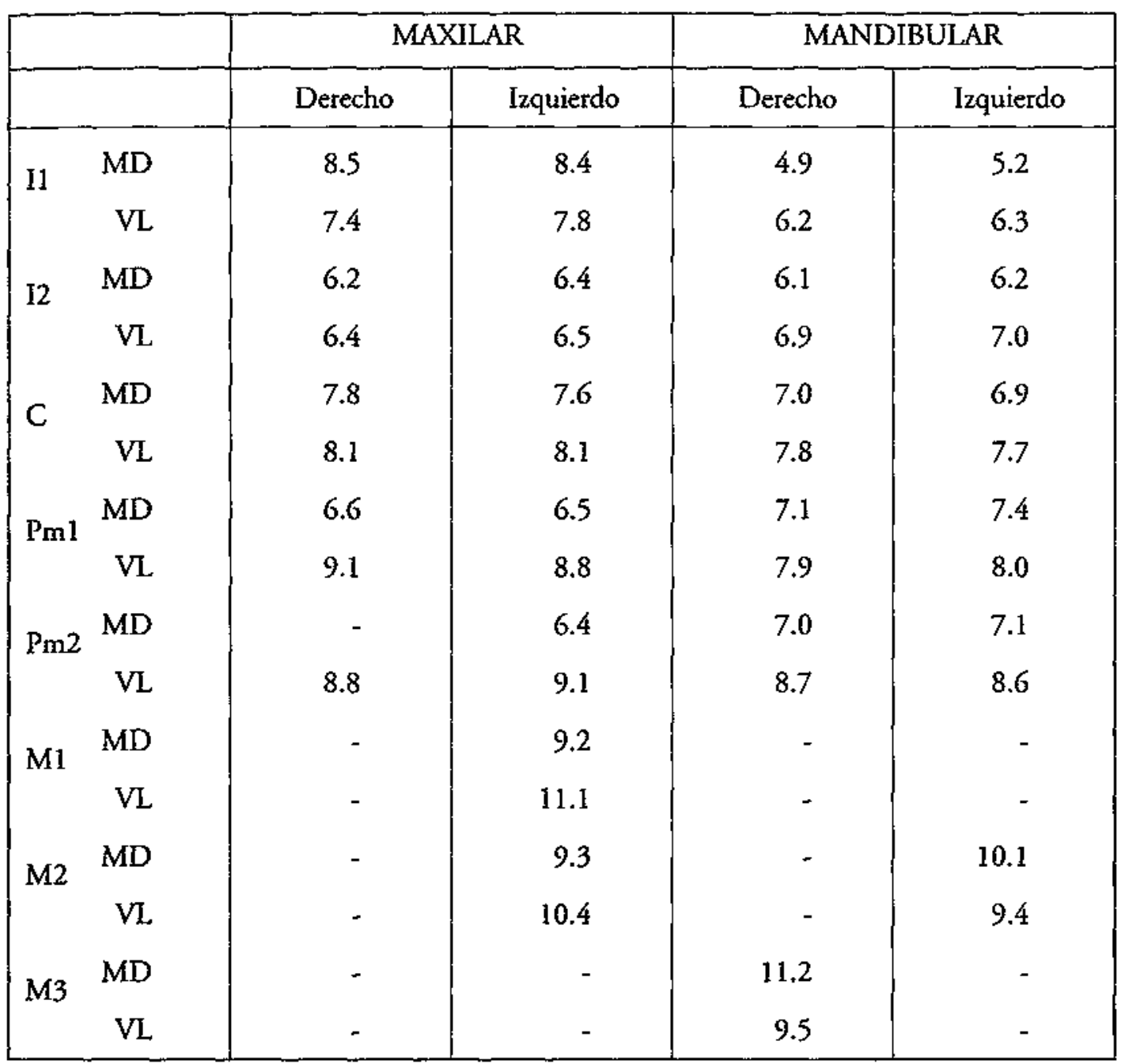




\section{CARACTERES METRICOS MANDIBULARES}

Individuo PR-07 (medidas en $\mathrm{mm}$., excepto indices en \%).

LONGITUD MANDIBULAR 108

LONGITUD DEL CUERPO MANDIBULAR ........................71

ANGULO MANDIBULAR

ANCHURA BICONDILEA

INDICE MANDIBULAR

$86,4^{*}$ Mandibula mesognata

ANCHURA BIGONLACA $90^{*}$

INDICE GONIOCONDILEO.

$72^{*}$

ALTURA DE LA RAMA

ANCHURA DE LA RAMA

INDICE DE LA RAMA 47,6

GROSOR CUERPO MANDIBULAR

NIVEL SINFISIS.

NIVEL PREMOLARES

ALTURA CUERPO

NIVEL SINFISIS. .34

NIVEL PREMOLARES

INDICE DE ROBUSTEZ

NIVEL SINFISIS 38,2

NIVEL PREMOLARES …........................................38,2

ANCHURA CONDILO

DISTANCIA ENTRE AGUJEROS MENTONLANOS.

* medidas tomadas por inferencia

MEDIDAS DEL ESPLACNOCRANEO

Individuo PR-07. (Todas las medidas en $\mathrm{mm}$.)

\begin{tabular}{|l|r|}
\hline ANCHURA BIZIGOMATICA & - \\
\hline ANCHURA FRONTAL MAXIMA & 125 \\
\hline ANCHURA FRONTAL MINIMA & 95 \\
\hline ALTURA TOTAL DE LA CARA & - \\
\hline ALTURA SUPERIOR DE LA CARA & 43 \\
\hline ALTURA MAXIMA DE LA ORBITA & 31 \\
\hline ANCHURA MAXIMA DE LA ORBITA & 40 \\
\hline ANCHURA MAXIMA DE LA ORBITA (DACRYON) & 38 \\
\hline ANCHURA NASAL MAXIMA & 21 \\
\hline ALTURA NASAL & 35 \\
\hline
\end{tabular}

Indice de la Orbita

775 Mesoconco

Indice Nasal ....

60.2 Hyperplatirrino 
MEDIDAS DE LOS HUESOS LARGOS

Individuo PR-07. (Todas las medidas en $\mathrm{mm}$.)

\begin{tabular}{|c|c|c|c|}
\hline HUESO & MEDIDA & DERECHO & IZQUIERDO \\
\hline \multirow{4}{*}{ HUMERO } & LONG. MAXIMA & 316 & 316 \\
\hline & PERIMETRO MINIMO & 59 & 59 \\
\hline & D. MAX. DIAFISIS & 20 & 20 \\
\hline & D. MIN DIAFISIS & 19 & 19 \\
\hline \multirow{2}{*}{ CUBITO } & LONG. MAXIMA & 272 & 265 \\
\hline & PERIMETRO MINIMO & 34 & 34 \\
\hline \multirow{2}{*}{ RADIO } & LONG. MAXIMA & 248 & 241 \\
\hline & PERIMETRO MINIMO & 40 & 38 \\
\hline \multirow{8}{*}{ FEMUR } & LONG. FISIOLOGICA & 431 & 435 \\
\hline & PERIMETRO DIAFISIS & 80 & 87 \\
\hline & D. SAGITAL DIAFISIS & 28 & 29 \\
\hline & D. TRANS. DIAFISIS & 24 & 26 \\
\hline & D. SAGITAL SUBTROC. & 23 & 24 \\
\hline & D. TRANS. SUBTROC. & 31 & 31 \\
\hline & ANCHURA EPIFISIS & 79 & - \\
\hline & D. DE LA CABEZA & 41 & - \\
\hline \multirow{8}{*}{ TIBLA } & LONG. MAXIMA & - & 364 \\
\hline & PERIMETRO MINIMO & 74 & 78 \\
\hline & D. SAGITAL & 23 & 22 \\
\hline & D. TRANSVERSAL & 35 & 36 \\
\hline & D. TUBEROSIDAD & - & 44 \\
\hline & ANCH. EPIFISIS SUP & - & 74 \\
\hline & ANCH. EPIFISIS INF. & - & - \\
\hline & CARILLAS TIBIALES & - & SI \\
\hline
\end{tabular}




\section{INDICES DEL ESQUELETO POSTCRANEAL}

Individuo PR-07.

Indice Clavículo-humeral

46.2 .

Indice de robustez de la clavícula izq.

20.54

Indice de robustez de humero izq. 18.67.

Indice diafisiario humero izq. 95.

Indice de robustez del Cúbito izq Eurybraquio

Indice de robustez del Radio Izq Indice de robustez del Femur Izq. Indice Platimérico del Femur Izq. Indice Pilástrico del Femur Izq. Indice de robustez de la Tibia izq. 12.83. 15.76 . 20. 77.41.Platimérico. 111.53. Medio.

Indice Platinécmico de la Tibia izq. 21.42 .

Indice braquial izquierdo 61.11.Platinécmico.

Indice braquial derecho. 75.8 .

Indice Humero-Femoral 78.4

Indice Crural 72.81 .

Indice Intermenbranal 83.87.

Estatura (Pearson) 69.92 . $1.56-1.62 \mathrm{~m}$. 

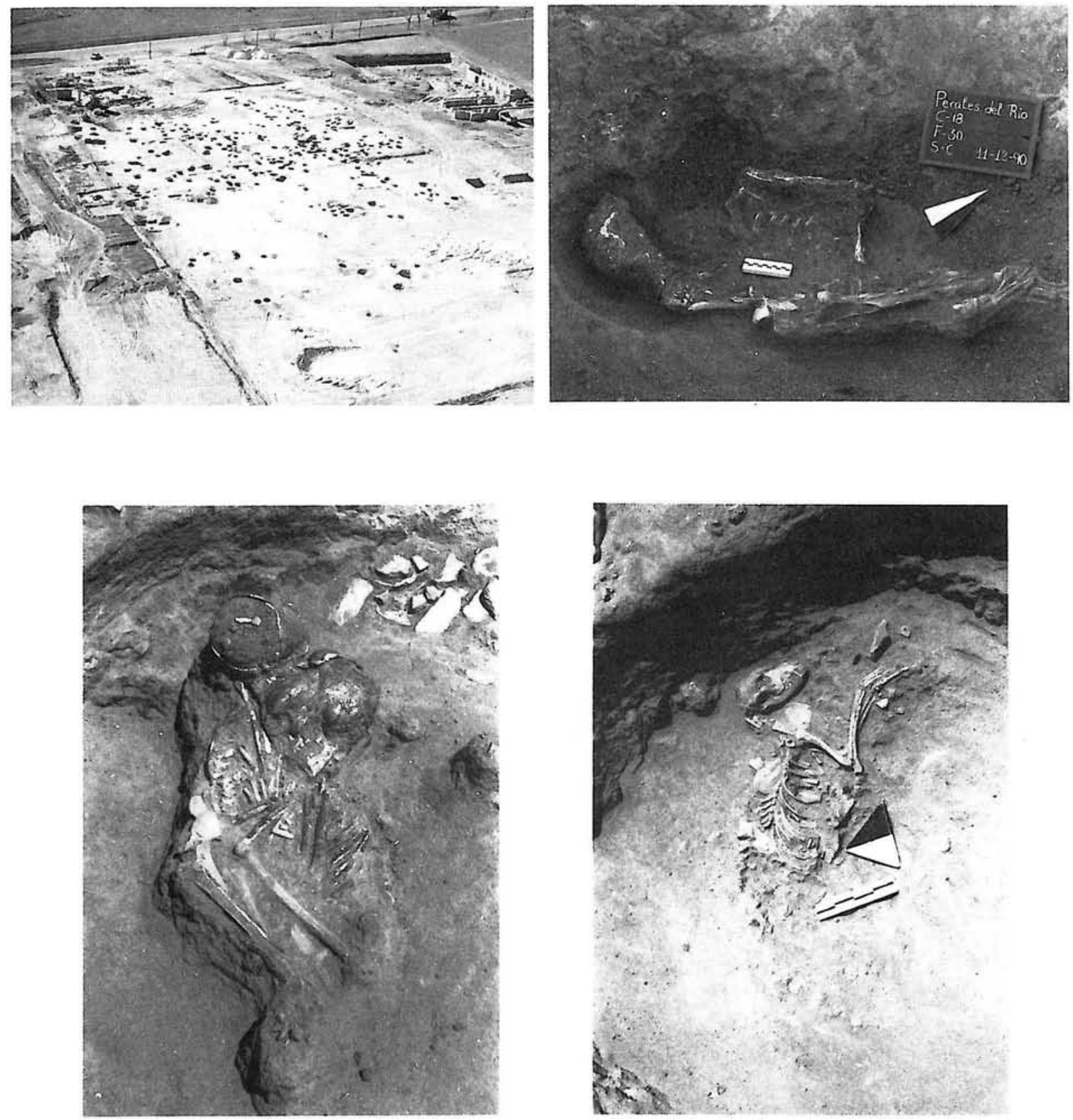

Lámina I.- a: Vista aérea del yacimiento del Caserío de Perales (Realizado por paisajes españoles).- b: Enterramiento del fondo 30 de la cuadrícula 18.- c: Enterramiento del fondo 23 de la cuadrícula 31.- d: Perro depositado como ofrenda en el enterramiento reproducido en la ilustración c de esta lámina I. 

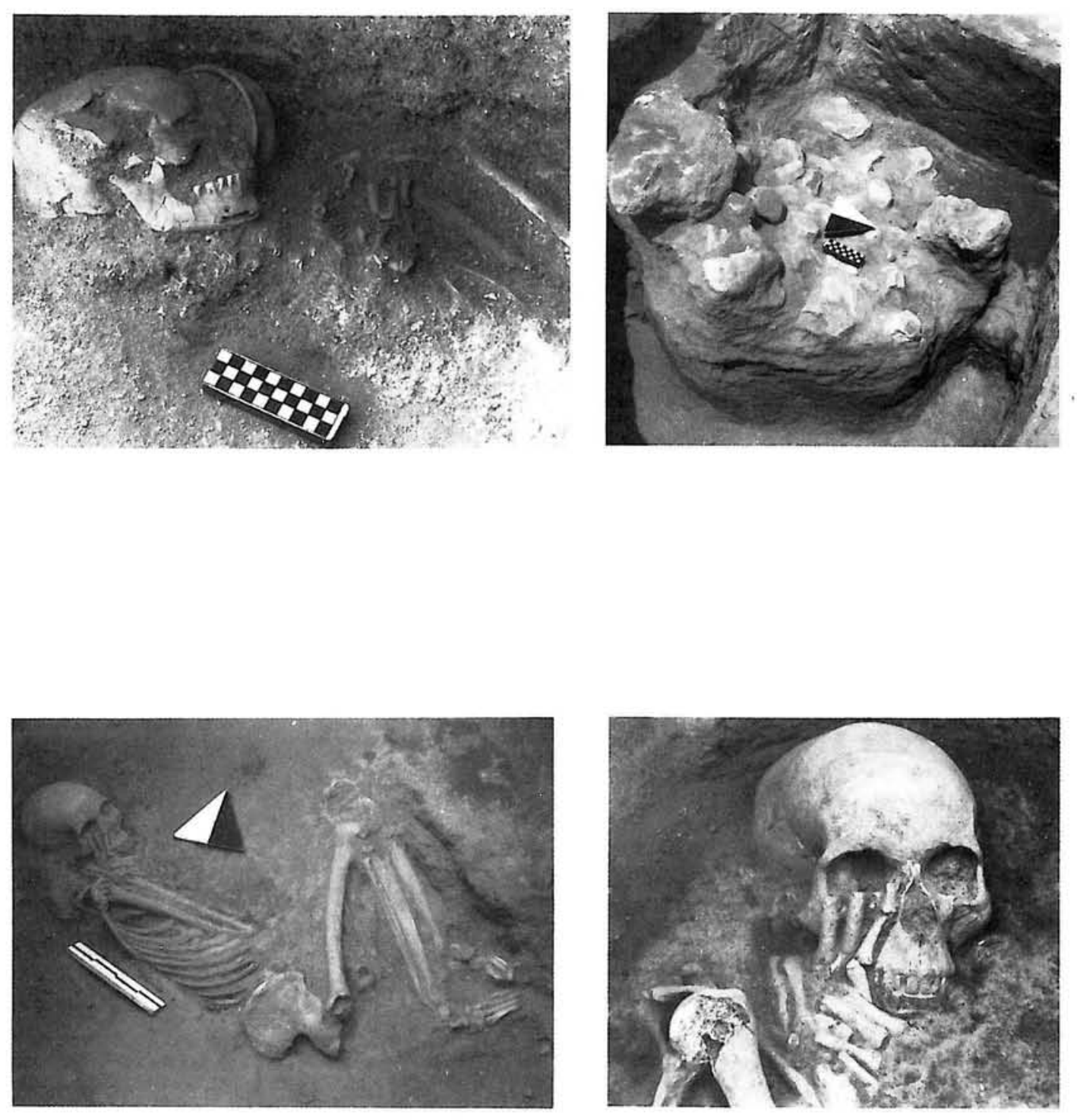

Lámina II.- a: Detalle del enterramiento del fondo del fondo 21 de la cuadrícula 43. Puede observarse la cazuela colocada sobre el temporal.- b: Acumulación de piedras colocadas sobre el enterramiento del fondo 11 de la cuadrícula 43.- c: Inhumación colocada bajo el túmulo de piedras de la ilustración b de esta misma lámina.- d: Detalle del mismo enterramiento. 

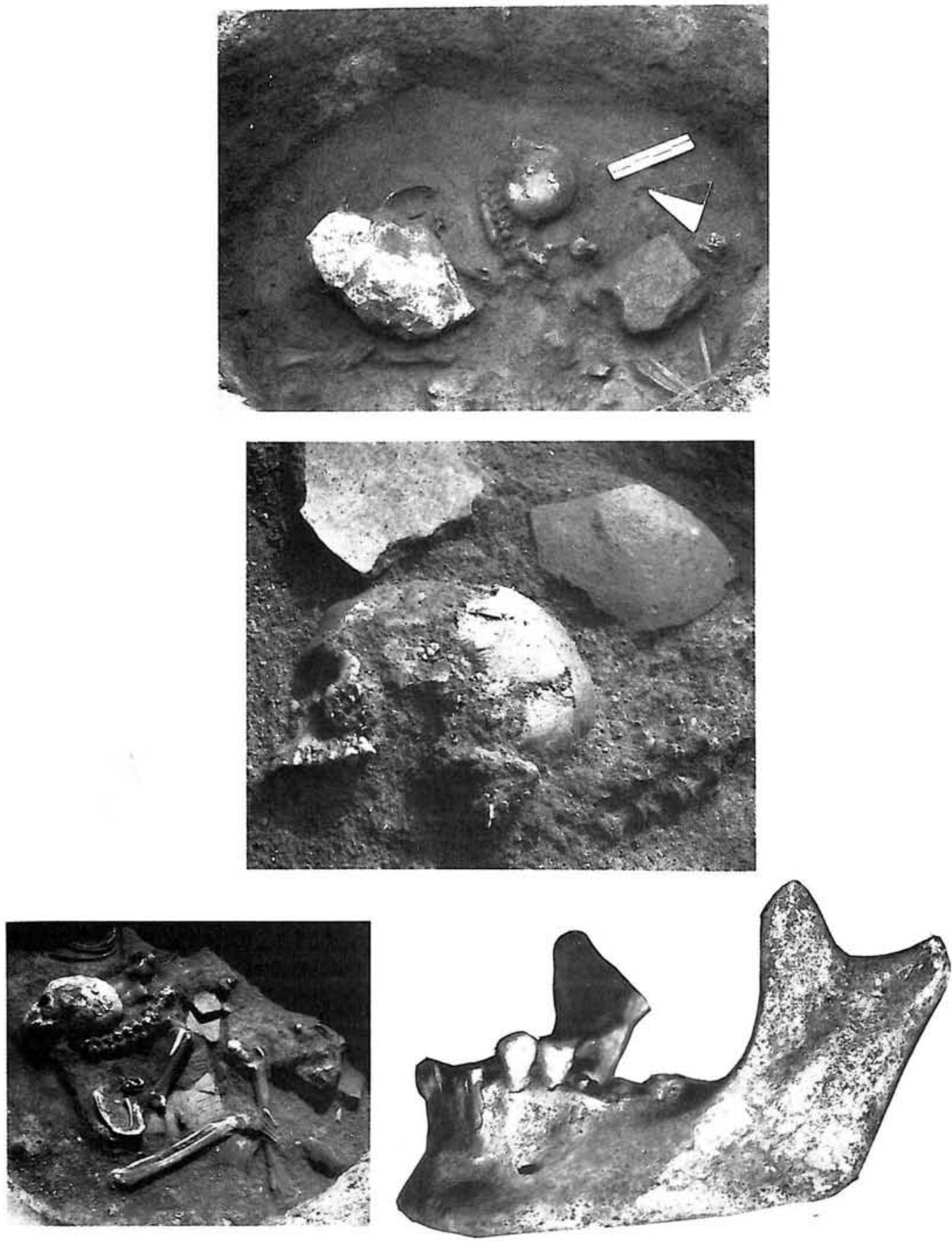

Lámina III.- a y c: Dos fases de la excavación del enterramiento de un cuerpo descoyuntado aparecido en el fondo 20 de la cuadrícula del mismo enterramiento.- b: Detalle del mismo enterramiento.- d: Mandíbula aparecida en el fondo 35 de la cuadrícula 29. 

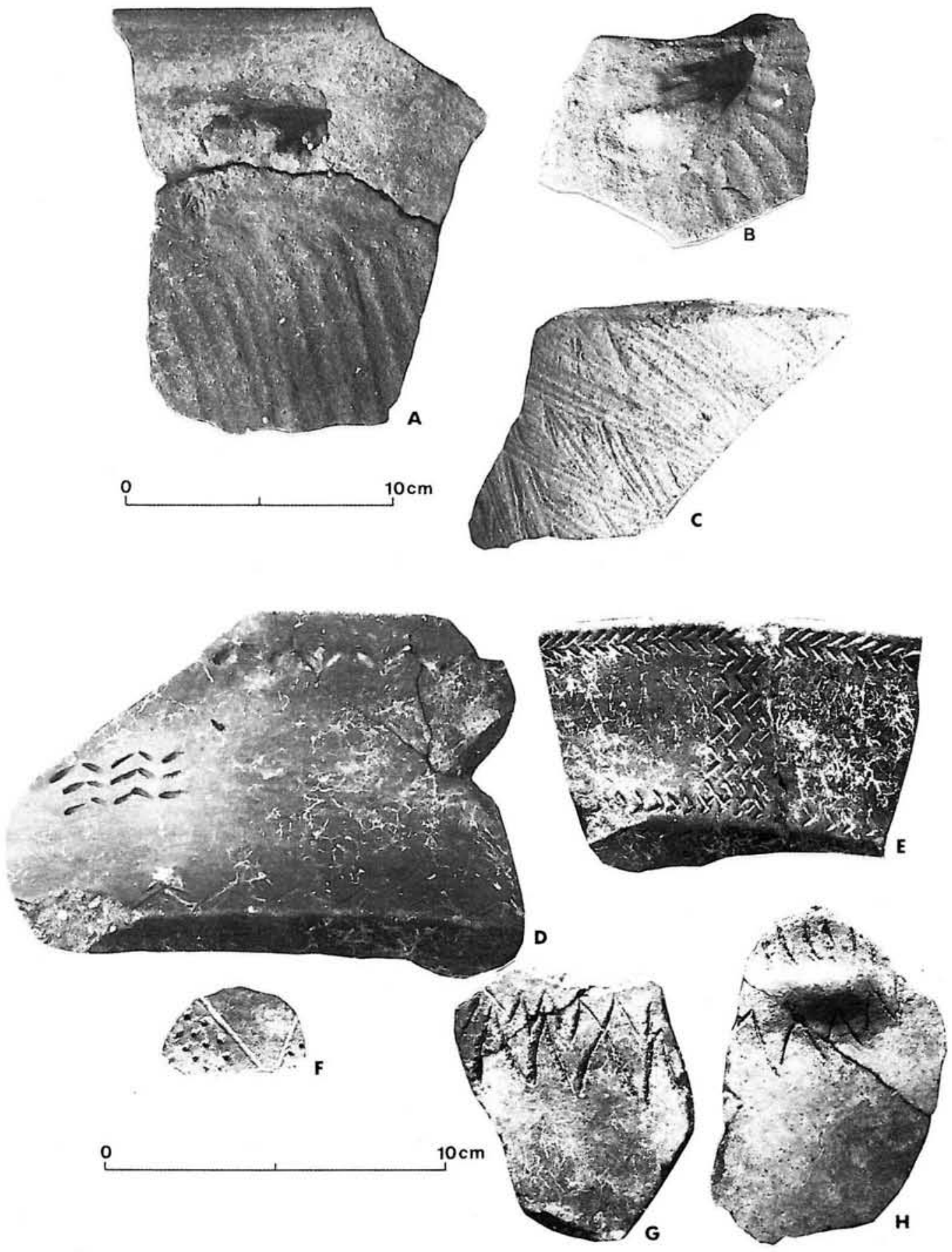

Lámina IV.- a, b y c: Detalle de los acabados de algunas de las superficies de fragmentos cerámicos recuperados en el fondo 20 de la cuadrícula 34/35.- d, e, f, g y h: Detalle de las decoraciones de algunos fragmentos cerámicos recuperados en el 23 de la cuadrícula 31. 